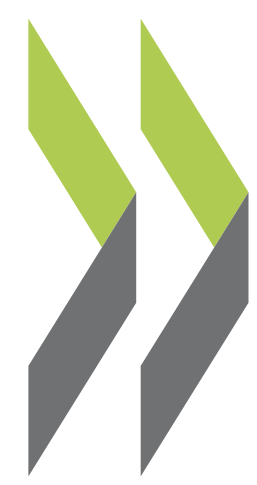

OECD Social, Employment and Migration Working Papers No. 79

Managing Highly-Skilled Labour Migration: A Comparative Analysis of Migration Policies and Jonathan Chaloff, Challenges in OECD

\title{
Georges Lemaître
}

\section{Countries}


Organisation de Coopération et de Développement Économiques

Organisation for Economic Co-operation and Development

18-Mar-2009

DIRECTORATE FOR EMPLOYMENT, LABOUR AND SOCIAL AFFAIRS

English - Or. English EMPLOYMENT, LABOUR AND SOCIAL AFFAIRS COMMITTEE

OECD SOCIAL, EMPLOYMENT AND MIGRATION WORKING PAPERS № 79

MANAGING HIGHLY-SKILLED LABOUR MIGRATION: A COMPARATIVE ANALYSIS OF MIGRATION POLICIES AND CHALLENGES IN OECD COUNTRIES

Jonathan Chaloff and Georges Lemaitre

JEL classification: F22; J24; J44; J61

JT03261489

Document complet disponible sur OLIS dans son format d'origine

Complete document available on OLIS in its original format 


\title{
DIRECTORATE FOR EMPLOYMENT, LABOUR AND SOCIAL AFFAIRS
}

\author{
http://www.oecd.org/els
}

\section{OECD SOCIAL, EMPLOYMENT AND MIGRATION WORKING PAPERS}

\author{
http://www.oecd.org/els/workingpapers
}

This series is designed to make available to a wider readership selected labour market, social policy and migration studies prepared for use within the OECD. Authorship is usually collective, but principal writers are named. The papers are generally available only in their original language - English or French - with a summary in the other.

Comment on the series is welcome, and should be sent to the Directorate for Employment, Labour and Social Affairs, 2, rue André-Pascal, 75775 PARIS CEDEX 16, France.

The opinions expressed and arguments employed here are the responsibility of the author(s) and do not necessarily reflect those of the OECD

\section{Applications for permission to reproduce or translate all or part of this material should be made to:}

\author{
Head of Publications Service \\ OECD \\ 2, rue André-Pascal \\ 75775 Paris, CEDEX 16 \\ France
}

Copyright OECD 2009 
DELSA/ELSA/WD/SEM(2009)5

\section{ACKNOWLEDGEMENTS}

The authors are grateful for the support and advice received from Pauline Fron, Jean-Christophe Dumont, Jean-Pierre Garson, Martine Durand and John Martin. 


\section{SUMMARY}

1. Most OECD countries expect growing shortages of highly-skilled labour in the coming two decades, and immigration is viewed as one way of addressing these. Most OECD countries have introduced policies aimed at facilitating the recruitment of such workers in recent years and efforts along these lines can be expected to continue. The document provides an overview of the issues related to the management of highly skilled labour migration.

2. In general, migrants are perceived as highly skilled when they have at least tertiary education, but other definitions are possible, notably on the basis of the nature of the occupation in which they are employed. One practical way of defining highly skilled migrants that has been used in some countries is by means of wages paid, with the highly skilled consisting of persons earning above a threshold value.

3. There are two principal ways of recruiting highly skilled workers from abroad. One is demanddriven, through employer requests. The other is supply-driven and involves inviting candidates to apply and selecting them on the basis of certain characteristics, among them age, educational attainment, language proficiency and occupation, for which points are assigned. Candidates having more than a threshold level of points are then granted the right to establish residence.

4. Supply-driven systems have been showing their limits in recent decades, with settlement countries finding it more difficult to select for success in the labour market. Employers appear to attribute less value to qualifications and work experience earned in a non-OECD country, so that immigrants arriving without jobs are having a harder time finding employment commensurate with their qualifications and experience.

5. One consequence has been a general trend towards transferring more of the responsibility for selecting migrants to employers. In this way, any qualifications and experience issues are dealt in the hiring negotiations between employers and workers prior to immigration. A second option is to favour candidates for migration with qualifications earned in an OECD country and indeed, in the host country itself. Most OECD countries have in fact introduced measures to allow international students to stay on after they complete their studies, provided they can find work of an appropriate level in their field of study.

6. Some countries, however, do not have significant basins of native-speakers outside their borders, so that hiring directly into jobs seems problematical, except in workplaces using an international language such as English. For such countries, some direct recruitment may still be possible, if an international language is widely spoken in the workplace. Otherwise supply-driven migration may have to be envisaged, with significant investments made in language teaching for new arrivals.

7. Active recruitment means more than just facilitating work permits for employers or for aspirant immigrants based on credentials. While high-skilled migrants may be attracted to countries with widely spoken languages and high wages regardless of the obstacles, a country with moderate wages and its own unique language will need to do more than just lower administrative barriers.

8. The effects of demographic change are only beginning to be felt in most countries. By 2010, more than half of OECD countries will show incoming labour force cohorts which are smaller than outgoing ones. The objective over the medium-term for OECD countries is to ensure the right scale and 
nature of movements to satisfy labour market needs. It would be premature to claim that all of the required policies are already in place.

Keywords: Management of migration; highly skilled migration; integration; demographic change 


\section{RÉSUMÉ}

9. La plupart des pays de l'OCDE s'attendent à des pénuries croissantes de travailleurs qualifiés dans les prochaines deux décennies, et l'immigration pourrait bien être une des réponses à ce phénomène. Ces dernières années, ils ont mis en place des politiques pour faciliter le recrutement de ces travailleurs et on peut s'attendre à ce qu'ils poursuivent leurs efforts dans ce sens. Ce document donne un aperçu des questions portant sur la gestion des travailleurs immigrés hautement qualifiés.

10. Généralement, un migrant hautement qualifié est sensé avoir au moins une éducation de niveau supérieur, mais d'autres définitions sont possibles, notamment sur la base de la profession exercée. Le niveau de salaire est aussi une référence pratique utilisée par certains pays pour considérer que les migrants hautement qualifiés sont les personnes qui reçoivent une rémunération au-dessus d'un certain seuil.

11. Il y a deux principaux moyens pour recruter des travailleurs hautement qualifiés résidant à l'étranger. Le premier est à l'initiative de la demande des employeurs. L'autre est fondé sur l'offre et consiste à inviter les candidats à postuler, et leur admission dépend de certains critères sélectifs comme l'âge, le niveau d'instruction, la maîtrise de la langue et la profession exercée. Il s'agit d'un système à points au-delà d'un certain niveau de points obtenus, les candidats ont le droit de s'installer dans le pays d'accueil.

12. Les systèmes fondés sur l'offre ont montré leurs limites au cours des décennies récentes, les pays d'accueil éprouvant des difficultés de recruter de manière à garantir une insertion réussie sur le marché du travail. Les employeurs semblent attribuer moins de valeur aux qualifications et à l'expérience professionnelle acquises dans un pays hors de la zone OCDE. Ainsi, les immigrés arrivant sans emploi préalable, éprouvent de sérieuses difficultés à trouver l'emploi correspondant à leur qualification et leur expérience.

13. En conséquence, on note une tendance générale à transférer à l'employeur tout ou partie de la responsabilité du processus de sélection des candidats à l'immigration. De cette façon, toutes les questions de qualification et d'expérience sont abordées dans le cadre des négociations d'embauche entre les employeurs et les personnes à recruter avant l'immigration. Une deuxième option est de favoriser les candidats à la migration ayant obtenu leurs qualifications dans un pays de l'OCDE et encore plus s'il s'agit du pays d'accueil lui-même. La plupart des pays de l'OCDE ont en fait adopté des mesures pour permettre aux étudiants étrangers ayant achevé leurs études, de rester dans le pays pour rechercher un emploi en relation avec leur niveau et leur domaine d'étude.

14. Dans certains pays, dont la langue nationale est peu parlée au-delà de leurs frontières, le recrutement direct reste problématique, sauf si la langue de travail est internationale, comme l'anglais. Pour de tels pays, le recrutement direct peut encore être possible, si une langue internationale est largement parlée dans les lieux de travail. Autrement, la migration impulsée par devrait être envisagée avec des investissements linguistiques importants demandés aux nouveaux arrivés.

15. Une politique active de recrutement signifie bien davantage que la simple possibilité d'accorder des permis à des employeurs ou à des candidats à l'immigration, sur la base de la reconnaissance de leur niveau de connaissance. Si les migrants hautement qualifiés peuvent être attirés, quels que soient les 
obstacles à surmonter, par des pays où les salaires sont élevés et dont les langues nationales sont largement parlées, les pays ayant une langue peu parlée en dehors du territoire national et offrant des salaires moins élevés ne pourront se contenter uniquement de la levée des barrières administratives.

16. Dans la plupart des pays, les effets de l'évolution démographique commencent tout juste à se faire sentir. Mais, à l'horizon 2010, plus de la moitié des pays de l'OCDE auront des cohortes entrantes de main d'œuvre moins nombreuses que les cohortes sortantes. L'objectif à moyen terme pour les pays d'OCDE est d'avoir des mouvements dont l'ampleur et la nature permettront de répondre aux besoins du marché du travail. Il serait prématuré de prétendre que toutes les politiques requises sont d'ores et déjà en place.

Mots clés: Gestion de la migration, migration de travailleurs hautement qualifiés, intégration ; les effets de l'évolution démographique 


\section{TABLE OF CONTENTS}

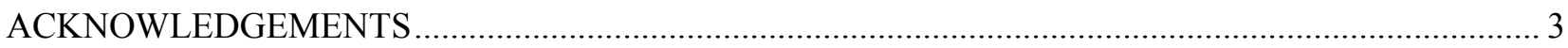

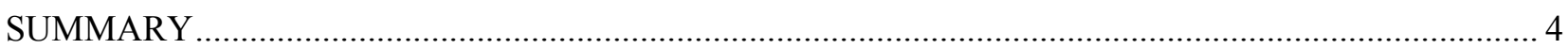

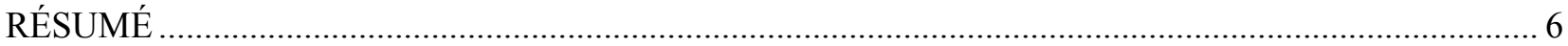

MANAGING HIGHLY-SKILLED LABOUR MIGRATION: A COMPARATIVE ANALYSIS OF MIGRATION POLICIES AND CHALLENGES IN OECD COUNTRIES ............................................ 10

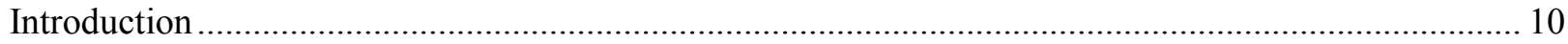

A. Overview of highly skilled migration in OECD countries ......................................................... 10

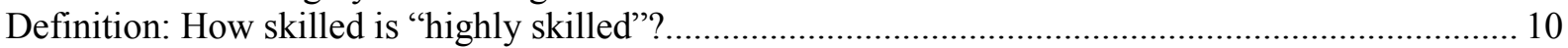

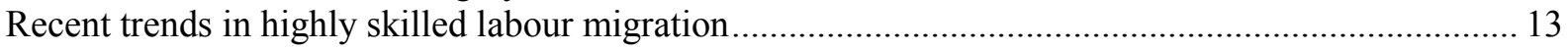

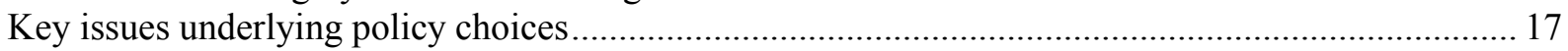

B. Current policies to manage labour migration of the highly skilled ............................................... 19

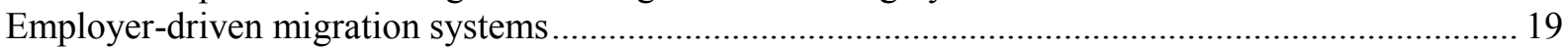

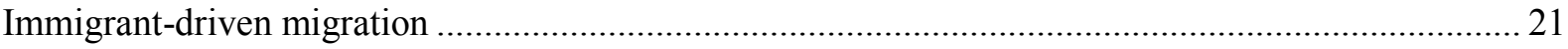

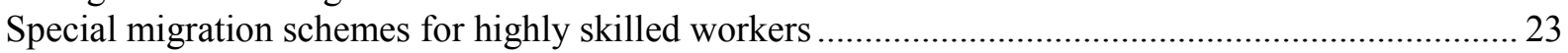

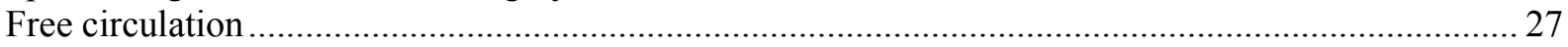

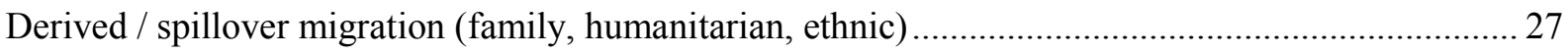

C. Critical issues in implementing migration policy for the highly skilled ..................................... 28

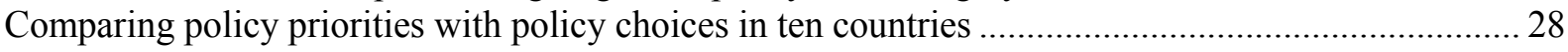

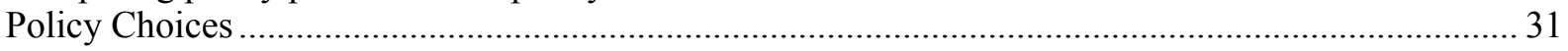

Qualifications, experience and language: key determinants for labour market outcomes..................... 38

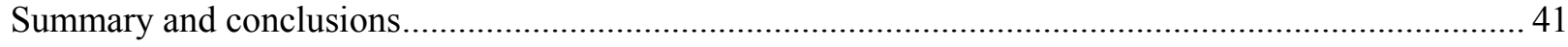

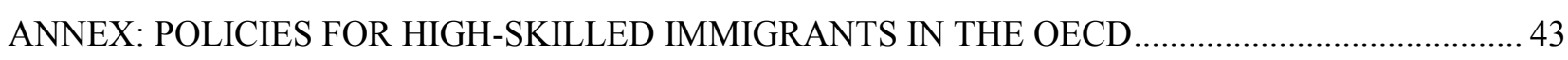

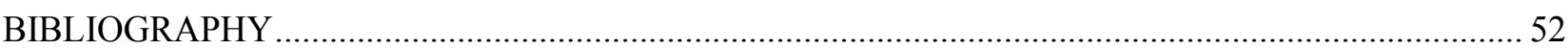

\section{Tables}

Table 1. Correspondence between persons with tertiary attainment and persons in professional or associate professional occupations, 2006 ........................................................................................ 13

Table 2. Size of the 15-19 cohort relative to that of the 60-64 cohort, based on the current age

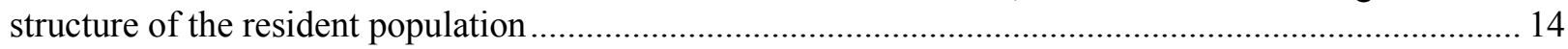

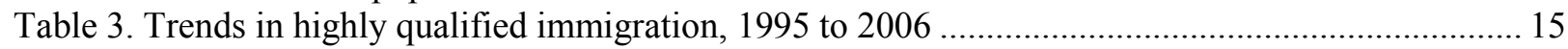

Table 4. Contribution of recent immigrations to employment in highly skilled occupations, $2006 \ldots \ldots \ldots . .16$

Table 5. Points attributed under different points systems for permanent residence in selected countries,

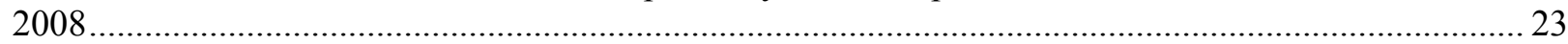

Table 6. Inflows of international students into selected OECD countries ('000s)................................. 24

Table 7. Flows of intra-company transfers, selected OECD countries, 2000-2006 .............................. 27

Table 8. Country comparison: Policy priorities and strategies for high-skilled migration ....................... 30

Table 9. Labour market outcomes of tertiary-educated native- and foregin-born persons, 15-64, 2005-2006 averages. 
DELSA/ELSA/WD/SEM(2009)5

\section{Boxes}

Box 1. A comparison of the Australian and United Kingdom points system ........................................ 22

Box 2. Skilled labour shortages, policy options, and migration of the highly skilled - the case of

Germany. 


\section{MANAGING HIGHLY-SKILLED LABOUR MIGRATION: A COMPARATIVE ANALYSIS OF MIGRATION POLICIES AND CHALLENGES IN OECD COUNTRIES}

\section{Introduction}

17. Over the past decade, the settlement countries of Australia, Canada, New Zealand and the United States, as well as Ireland, Switzerland and the United Kingdom, saw significant rises in their intake of highly skilled labour migrants. More recently, a number of OECD countries have seen a notable increase in the migration of medical personnel. The next two decades will likely be characterised by heightened shortages of skilled workers as youth cohorts enter the labour force which are smaller than those retiring. New flows of labour migrants may well be one response to this development, especially in certain European OECD countries, as well as in Japan and Korea, where demographic decline promises to be more significant. However, in some OECD countries, the growing educational attainment among young cohorts entering the work force, the mobilisation of available labour reserves, in particular among women and older workers, and further declines in unemployment could play a non-negligible role in attenuating in part anticipated tightness in the labour market.

18. In any event, given the growing importance of the knowledge economy, competition will be more intense among countries of the OECD zone and perhaps beyond to attract and retain highly qualified workers (Wyckoff and Schapper, 2005). Under these conditions, selective migration policies, which already play an important role, will be the object of growing attention among policy makers in OECD countries.

19. The aim of this document is to provide a preliminary overview of policies and issues related to the management of highly skilled labour migration. A definition of "highly skilled" opens the discussion, followed by an overview of recent movements concerning this type of migration in OECD countries as well as key issues underlying policy choices (Section A). The latter have already introduced many measures to facilitate movements of highly skilled migrants, described in the subsequent section, as well as having the means in place to ensure that movements are in response to actual needs (Section B). A comparative approach of policy priorities with choices in ten countries is presented, followed by a discussion of the critical issues in implementing migration policies for the highly-skilled, with a view to highlighting what the policy options are (Section C). A summary with conclusions ends the discussion. A synthesis table summarising the main characteristics of migration regimes and special schemes to recruit the highly skilled in almost all OECD countries is presented in an Annex.

\section{A. Overview of highly skilled migration in OECD countries}

\section{Definition: How skilled is "highly skilled"?}

20. In general discussions about highly skilled migration, the implicit definition of a highly skilled migrant is one with a university degree. In references to the "best and the brightest", however, and to the need to attract such migrants to ensure continuing innovation and international competitiveness, the underlying impression conveyed is of a relatively small elite, covering perhaps persons with doctorates, researchers, high-level engineers. How large is this group? 
21. Data for the United States indicate that about $10 \%$ of the foreign-born have a professional, masters or doctorate degree (Grieco, 2004). Among recent (2006) permanent immigrants to Canada who intend to work in Canada after arrival, approximately $8 \%$ have a masters or doctorate. If one goes beyond this small group, persons with a bachelor's degree account for an additional $25 \%$ and persons with a postsecondary non-university qualification (including trade certificates) a further $21 \%$ (CIC, 2006). This covers all migration categories. The percentages in the more highly skilled group would be even larger if one were to restrict the population to those directly selected through the Canadian point system.

22. Although the small highly educated elite is clearly a significant priority for many countries, the demographic change currently under way in OECD countries is likely to result in labour needs across a broader segment of persons with better than upper secondary education levels. Both the Australian and Canadian point systems currently grant points for qualifications that are not university degrees or for occupations that are traditionally associated with qualifications "lower" than a bachelor's degree. A survey of small and medium enterprises in Canada indicated that anticipated labour needs were more concentrated in technical and lower professional occupations that in those requiring a university degree (Canadian Federation of Independent Business, 2006). The French list of skilled shortage occupations for which enterprises may recruit immigrants from around the world includes many occupations which also do not require a university degree ${ }^{1}$.

23. For the purposes of this document, "highly skilled" from an educational perspective will be considered to include post-secondary education that is university-level but that may involve a vocational, technical or professional qualification of shorter duration than a bachelor's degree. This covers many of the technical occupations referred to above. The cut-off specified here is arbitrary but corresponds approximately to tertiary education, as defined in the International Standard Classification of Education (ISCED). Note that this definition of tertiary does not generally include trade or apprenticeship-based occupations. Educational attainment, however, is not the only criterion of identification of the highly skilled. In the Australian general skilled migration programme, applicants must have an occupation on a skilled occupation list to be considered (Skilled Occupation List) ${ }^{2}$. However, it remains true that applicants must have a qualification that meets Australian standards and generally corresponds to at least a postsecondary diploma. For statistics based on the International Standard Classification of Occupations (ISCO), highly skilled will be taken to mean occupations including managers, professionals and associate professionals. $^{3}$

24. The statistics presented in this document will generally refer to the educational or occupational definitions of highly skilled. There is, however, a more empirical definition that is also commonly used to specify skill levels.

25. In employer-initiated migration (see below), the wage level of the job to be held is used in certain countries as an indicator of the skill level and indeed is deemed to be a better predictor of long-term labour market success than a formal qualification which employers other than the one recruiting the immigrant initially may not necessarily recognise. ${ }^{4}$ In Tier 1 of the United Kingdom migration program, the successor

1 The regional lists include woodworkers, glassmakers, metalworkers, etc. (www.anaem.fr/IMG/pdf/conference_presse_8_Nov_2007/listedes_metiers_1.pdf)

2 The Skilled Occupation List (http://www.immi.gov.au/allforms/pdf/1121i.pdf) includes Professional, Administrative/Management, and Trades categories.

3 Managers of small enterprises are excluded because they include owners of small shops and businesses.

4 If an immigrant seeks to change jobs, the previous work experience obtained in the host country is likely to be a more important indicator of adaptability and productivity for the new employer than a foreign formal qualification. 
to the Highly Skilled Migration Programme where candidates for migration need not have a job offer, points are awarded on the basis of the salary earned in the origin country.

26. In both of these cases, there is clearly considerable flexibility in setting a wage threshold level for "highly skilled". The wage-level criterion ensures that the qualifications and work experience of a candidate for immigration has been valued at a certain level in a labour market, if not necessarily the domestic one, a result that is at best implicit and not necessarily guaranteed if a candidate is assessed on the basis of a formal qualification. In any event, if a certain minimum educational level is required for the issuance of a permit, the equivalence of a foreign qualification to a domestic one may be difficult to formally determine by an immigration official. This issue of the equivalence between foreign and domestic qualifications and experience is a recurring theme with respect to highly skilled migration and will receive more extensive treatment below.

27. The three definitions of highly skilled outlined here (based on education, occupation or wage level) overlap to some extent. Indeed the degree of non-overlap has been the object of a number of analyses, for example concerning persons with tertiary attainment occupying jobs for which they are formally overqualified, (see OECD, 2007a). However, the opposite situation also exists, that is, that of persons with less than tertiary education holding highly skilled jobs for which they do not have the current entry-level formal qualifications (OECD, 2002). The three definitions have been retained here, essentially because all three are used by host countries in identifying potential highly qualified candidates for immigration. In practice, the data presented below will refer to the definitions based on education or occupation. Table 1 provides an indication of the extent of agreement between the two classifications. On average about one half of persons with tertiary education or in high-skilled jobs would be highly qualified by either definition. 
Table 1. Correspondence between persons with tertiary attainment and persons in professional or associate professional occupations, 2006

\begin{tabular}{|c|c|c|c|c|c|}
\hline & Tertiary educated & $\begin{array}{l}\text { Professionals } \\
\text { and associate } \\
\text { professionals }\end{array}$ & Underqualified & $\begin{array}{l}\text { Education and job } \\
\text { requirements } \\
\text { correspond }\end{array}$ & Overqualified \\
\hline & \multicolumn{2}{|c|}{ Percent of persons employed ${ }^{1}$} & \multicolumn{3}{|c|}{ Percent of reference population ${ }^{1,2}$} \\
\hline Austria & 17 & 33 & 54 & 34 & 12 \\
\hline Czech Republic & 13 & 35 & 63 & 34 & 3 \\
\hline Italy & 15 & 34 & 58 & 36 & 6 \\
\hline Slovak Republic & 15 & 32 & 55 & 40 & 5 \\
\hline Germany & 25 & 39 & 45 & 42 & 12 \\
\hline Switzerland & 27 & 42 & 43 & 44 & 13 \\
\hline France & 27 & 34 & 32 & 52 & 16 \\
\hline Spain & 33 & 26 & 14 & 52 & 33 \\
\hline Hungary & 19 & 29 & 40 & 52 & 8 \\
\hline Netherlands & 29 & 41 & 37 & 53 & 10 \\
\hline Poland & 20 & 28 & 35 & 53 & 11 \\
\hline Ireland & 34 & 27 & 16 & 54 & 30 \\
\hline United Kingdom & 29 & 31 & 26 & 54 & 20 \\
\hline Sweden & 29 & 41 & 36 & 54 & 10 \\
\hline Portugal & 14 & 20 & 35 & 56 & 9 \\
\hline Belgium & 36 & 38 & 24 & 56 & 20 \\
\hline Finland & 32 & 38 & 28 & 56 & 16 \\
\hline Denmark & 32 & 40 & 30 & 60 & 11 \\
\hline Luxembourg & 26 & 42 & 38 & 60 & 2 \\
\hline Norway & 33 & 39 & 27 & 60 & 13 \\
\hline Greece & 25 & 26 & 19 & 64 & 17 \\
\hline Average & 25 & 34 & 36 & 51 & 13 \\
\hline \multicolumn{6}{|c|}{ Notes: 1. Excludes managers and persons in the armed forces (ISCO 0 and 1). } \\
\hline \multicolumn{6}{|c|}{$\begin{array}{l}\text { 2.The reference population consists of persons with either tertiary education (ISCED } 5 / 6 \text { ) or in professional or associate professional } \\
\text { occupations (ISCO 2/3). Overqualified persons are those with a tertiary education who work in other than professional or associate } \\
\text { professional occupations. Underqualifed persons are those with less than upper secondary education who work in professional or associate } \\
\text { professional occupations. Finally those where there is correspondence are those for whom there is agreement between the formal } \\
\text { educational qualifications and the skill level of the job. }\end{array}$} \\
\hline
\end{tabular}

\section{Recent trends in highly skilled labour migration}

28. Current demographic trends point to a significant decline in the working-age population in many OECD countries over the next fifteen years, as retiring cohorts are replaced by smaller youth cohorts. Table 2 shows the size of the incoming cohort aged 15-19 relative to the outgoing one aged 60-64 for each OECD country over the period 2005 to 2020 , assuming zero net migration and no deaths. Denmark, Germany, Italy and Japan already in 2005 had retiring cohorts that were larger than incoming ones. With each additional five years, the number of OECD countries in the same position increases. By 2020, all but Ireland, Mexico and Turkey are projected to experience a decline in the working-age population, based on the current age structure of the population. At that time OECD countries as a whole (excluding Mexico and Turkey) will have youth cohorts that are on average only $80 \%$ of the size of retiring older cohorts. 
Table 2. Size of the 15-19 cohort relative to that of the 60-64 cohort, based on the current age structure of the resident population

Australia
Austria
Belgium
Canada
Czech Republic
Denmark
Finland
France
Germany
Greece
Hungary
Iceland
Ireland
Italy
Japan
Luxembourg
Mexico
Netherlands
New Zealand
Norway
Poland
Portugal
Korea
Slovak Republic
Spain
Sweden
Switzerland
Turkey
United Kingdom
United States

All countries

-- excluding Mexico and Turkey

Percentages

\begin{tabular}{rrrr}
2005 & 2010 & 2015 & 2020 \\
\hline 147 & 112 & 98 & 86 \\
102 & 99 & 83 & 64 \\
125 & 95 & 83 & 73 \\
141 & 105 & 80 & 65 \\
111 & 77 & 58 & 67 \\
94 & 91 & 95 & 88 \\
112 & 80 & 75 & 75 \\
143 & 89 & 90 & 90 \\
94 & 98 & 70 & 57 \\
111 & 80 & 73 & 66 \\
111 & 93 & 64 & 66 \\
179 & 146 & 115 & 99 \\
172 & 123 & 115 & 115 \\
87 & 72 & 71 & 67 \\
78 & 58 & 69 & 74 \\
129 & 110 & 97 & 79 \\
362 & 327 & 237 & 198 \\
119 & 89 & 89 & 83 \\
169 & 133 & 112 & 96 \\
126 & 104 & 101 & 89 \\
194 & 103 & 67 & 58 \\
110 & 88 & 81 & 77 \\
157 & 144 & 107 & 62 \\
172 & 115 & 72 & 64 \\
111 & 85 & 76 & 73 \\
106 & 96 & 81 & 84 \\
105 & 97 & 85 & 64 \\
357 & 279 & 215 & 165 \\
127 & 98 & 97 & 86 \\
166 & 125 & 100 & 91 \\
145 & 116 & 100 & 90 \\
126 & 98 & 86 & 78
\end{tabular}

Number of countries for which the 15-19 cohort is smaller than the $60-64$ cohort.

Source: UN population prospects, 2006.

Notes: The estimates are obtained by aging younger five-year age cohorts, assuming zero net migration and no deaths. The estimate of the 15-19 cohort in 2010, for example, is taken to be the size of the $10-14$ cohort in 2005

29. These projections, however, tend to exaggerate the extent of likely labour market demand for high-skilled workers, because the younger cohorts will be more educated than the older outgoing ones. However, it is less this mechanical accounting relationship which matters than the fact that entry-level educational requirements for jobs of all kinds have risen and that these will be difficult to satisfy in the presence of smaller youth cohorts.

30. The past decade has seen a substantial increase in the employment of recent immigrants with tertiary attainment (Table 3), with the number of such immigrants employed in 2006 being generally several times larger than the corresponding number in 1995. This is especially the case for more recent immigration countries such as Ireland, Italy, Norway and Spain, but even long-standing immigration countries such as Belgium, France and Luxembourg have seen strong increases in the number of employed recent immigrants with tertiary attainment. A similar picture emerges for immigrants working as managers, professionals and associate professionals, but the increase over the decade is not so large, suggesting that more of the recent immigrants in 2006 are having difficulties finding jobs commensurate with their qualifications. 
DELSA/ELSA/WD/SEM(2009)5

Table 3. Trends in highly qualified immigration, 1995 to 2006

\begin{tabular}{|c|c|c|c|c|c|c|c|c|}
\hline & \multicolumn{4}{|c|}{$\begin{array}{c}\text { Employed immigrants with tertiary education having arrived in } \\
\text { previous ten years }\end{array}$} & \multicolumn{4}{|c|}{$\begin{array}{c}\text { Employed immigrants working as managers }{ }^{1} \text {, professionals } \\
\text { and associate professionals having arrived in previous ten } \\
\text { years }\end{array}$} \\
\hline & \multirow[t]{2}{*}{$\begin{array}{l}\text { Number in } 2006 \text { relative } \\
\text { to number in } 1995\end{array}$} & \multicolumn{3}{|c|}{$\begin{array}{l}\text { As a percent of all employed } \\
\text { immigrants having arrived in } \\
\text { previous ten years }\end{array}$} & \multirow[t]{2}{*}{$\begin{array}{l}\text { Number in } 2006 \\
\text { relative to number in } \\
1995\end{array}$} & \multicolumn{3}{|c|}{$\begin{array}{l}\text { As a percent of all employed } \\
\text { immigrants having arrived in previous } \\
\text { ten years }\end{array}$} \\
\hline & & 1995 & 2006 & $2006 / 1995$ & & 1995 & 2006 & $2006 / 1995$ \\
\hline Austria & 1.9 & 13.2 & 27.3 & 2.1 & 1.3 & 19.6 & 29.1 & 1.5 \\
\hline Belgium & 3.0 & 45.3 & 43.3 & 1.0 & 2.9 & 40.0 & 36.8 & 0.9 \\
\hline Switzerland &.. & .. & 45.2 &.. & .. & .. & 49.9 &.. \\
\hline Czech Republic & .. & .. & 28.6 & .. & .. & .. & 28.8 & .. \\
\hline Germany & .. & .. & 29.1 & .. & .. & .. & 25.5 & .. \\
\hline Denmark & 2.9 & 38.5 & 44.3 & 1.2 & 2.7 & 33.5 & 34.9 & 1.0 \\
\hline Spain & 25.8 & 39.5 & 23.9 & 0.6 & 10.9 & 31.8 & 8.1 & 0.3 \\
\hline Finland & & & 21.2 & & & & 34.7 & \\
\hline France & 4.1 & 31.7 & 36.9 & 1.2 & 2.9 & 34.5 & 28.5 & 0.8 \\
\hline Greece & 1.4 & 18.7 & 12.5 & 0.7 & 0.7 & 10.1 & 3.6 & 0.4 \\
\hline Hungary & .. & .. & 31.1 & .. & .. & .. & 28.8 & .. \\
\hline Ireland & 7.7 & 56.1 & 49.2 & 0.9 & 7.9 & 35.4 & 25.6 & 0.7 \\
\hline Italy & 8.2 & 23.5 & 12.5 & 0.5 & 7.1 & 18.8 & 8.6 & 0.5 \\
\hline Luxemboug & 3.4 & 24.6 & 48.7 & 2.0 & 3.1 & 30.3 & 55.2 & 1.8 \\
\hline Netherlands & 1.3 & 26.6 & 29.6 & 1.1 & 1.2 & 29.4 & 29.4 & 1.0 \\
\hline Norway & 10.0 & 6.6 & 31.8 & 4.8 & .. & .. & 25.2 & .. \\
\hline Poland & .. & .. & 49.2 & .. & .. & .. & 56.6 & .. \\
\hline Portugal & 4.2 & 16.6 & 15.9 & 1.0 & 2.0 & 20.7 & 9.6 & 0.5 \\
\hline Sweden & 1.7 & 38.3 & 45.4 & 1.2 & .. & .. & 33.8 & .. \\
\hline Slovak Republic & .. & .. & 16.7 & .. & .. & .. & 56.1 & .. \\
\hline United Kingdom & .. & .. & .. & .. & .. & 46.2 & 38.6 & 0.8 \\
\hline United States & 1.4 & 29.6 & 31.2 & 1.1 & 0.9 & 21.9 & 14.6 & 0.7 \\
\hline Average & 5.5 & 29.2 & 32.1 & 1.1 & 3.6 & 28.6 & 30.1 & 1.1 \\
\hline
\end{tabular}

Sources : European Community Labour Force Survey for European countries, Current Population Survey for the United States. Data for the United States refer to 1998 Notes: The designation "managers" excludes managers of small enterprises (ISCO 13), which covers small shopkeepers.

31. Despite the large increases in the numbers of recent highly qualified immigrants who are employed, however, the share of the highly qualified among employed recent immigrants has not increased in anywhere near the same proportions. Indeed the increase is, on average, only about $10 \%$ for the countries shown, whether the skilled criterion is an educational or occupational one. Only in Austria, Luxembourg and Norway does one see a much larger increase. In some other countries, e.g. Spain, Greece, Italy and Portugal, the share of the high-skilled among employed recent immigrants is much lower than that observed among immigrants who arrived in the ten years prior to 1995.

32. These results do not necessarily contradict the public discourse about the need for highly skilled migration. Rather they illustrate that lesser skilled migration has been as common, indeed more common in many countries over the past decade compared with the previous one. Whether this will continue into the future is uncertain. The demographic pinch was only just beginning to exert its effect as of 2006, with the retirement of workers born in the post-war years. Although Table 3 suggests that highly qualified migration does not appear to be manifesting itself more strongly as yet, it seems unlikely to escape the impact of demographic change.

33. What has been the contribution of recent immigration to employment in high-skill occupations? Table 4 attempts to assess this on the basis of data for 2006, where recent immigrants are defined as those who entered over the previous ten years. In attempting such an assessment, however, one needs to identify 
an appropriate reference population of native-born persons who have recently entered such occupations. The ideal population of reference would be persons who completed their education over the previous ten years. For the sake of simplicity, however, the reference group chosen for the table was a ten-year cohort of native-born persons, in particular that of native-born persons aged 30-39. This particular age group was chosen (rather than 25-34 year olds) to ensure that all persons in the cohort had completed their education. ${ }^{5}$ The share of recent arrivals employed in highly qualified occupations was then calculated as a percentage of all employed "new entrants" in such occupations over a 10-year period, where the latter consisted of the total of recent immigrants (those having arrived over the last ten years) plus native-born persons aged 30-39 in such occupations.

Table 4. Contribution of recent immigrants to employment in highly skilled occupations, 2006

\begin{tabular}{|c|c|c|c|c|c|c|}
\hline & Persons in $\mathrm{e}$ & mployment & Persons in hig & h-skilled jobs & Professi & sionals \\
\hline & $\begin{array}{l}\text { Employed immigrants as } \\
\text { a percentage of totals } \\
\text { employment }\end{array}$ & $\begin{array}{l}\text { Employed immigrants } \\
\text { having arrived in } \\
\text { previous ten years as } \\
\text { new entrants }\end{array}$ & $\begin{array}{l}\text { Immigrants in high-skill } \\
\text { jobs }^{2} \text { as a percentage of } \\
\text { all persons in high-skill } \\
\text { jobs }\end{array}$ & $\begin{array}{l}\text { Immigrants in high-skill } \\
\text { jobs having arrived in } \\
\text { previous ten years as a } \\
\text { percentage of new } \\
\text { entrants }^{1} \text { in high-skill } \\
\text { jobs }\end{array}$ & $\begin{array}{l}\text { Immigrant professionals } \\
\text { as a percentage of all } \\
\text { professionals in } \\
\text { employment }\end{array}$ & $\begin{array}{l}\text { Immigrant professionals } \\
\text { having arrived in } \\
\text { previous ten years as a } \\
\text { percentage of new } \\
\text { entrant }{ }^{1} \text { professionals }\end{array}$ \\
\hline Austria & 15.4 & 17.1 & 11.2 & 12.6 & 14.7 & 18.0 \\
\hline Belgium & 11.1 & 12.0 & 9.8 & 10.6 & 9.5 & 10.4 \\
\hline Switzerland & 24.4 & 32.1 & 20.9 & 30.4 & 23.4 & 35.9 \\
\hline Czech Republic & 1.8 & 3.0 & 1.5 & 2.4 & 2.1 & 4.3 \\
\hline Germany & 13.3 & 12.7 & 9.0 & 7.6 & 9.4 & 9.4 \\
\hline Denmark & 5.8 & 8.7 & 5.0 & 6.0 & 6.5 & 8.1 \\
\hline Spain & 14.6 & 30.2 & 7.3 & 9.8 & 7.7 & 10.0 \\
\hline Finland & 2.8 & 3.9 & 2.4 & 2.8 & 3.1 & 4.3 \\
\hline France & 11.2 & 8.1 & 9.4 & 5.9 & 11.1 & 7.7 \\
\hline Greece & 8.3 & 13.0 & 2.5 & 1.8 & 2.4 & 1.5 \\
\hline Hungary & 1.8 & 1.8 & 2.1 & 1.7 & 2.9 & 2.9 \\
\hline Ireland & 13.7 & 26.0 & 13.7 & 23.5 & 14.6 & 25.6 \\
\hline Italy & 8.5 & 13.2 & 3.9 & 3.5 & 4.2 & 3.6 \\
\hline Luxembourg & 43.8 & 54.3 & 42.9 & 59.0 & 48.2 & 62.6 \\
\hline Netherlands & 10.3 & 8.7 & 8.2 & 5.7 & 8.5 & 6.8 \\
\hline Norway & 7.4 & 11.6 & 6.4 & 6.2 & 8.2 & 8.0 \\
\hline Poland & 0.3 & 0.5 & 0.5 & 0.8 & 0.5 & 0.8 \\
\hline Portugal & 7.8 & 9.8 & 9.6 & 4.4 & 10.0 & 4.5 \\
\hline Sweden & 12.5 & 11.1 & 9.7 & 8.0 & 11.0 & 10.2 \\
\hline Slovak Republic & 0.7 & 0.2 & 0.9 & 0.3 & 1.2 & 0.2 \\
\hline United Kingdom & 11.0 & 18.9 & 11.8 & 17.0 & 14.2 & 22.1 \\
\hline United States & 15.8 & 22.8 & 12.5 & 14.5 & 18.0 & 23.5 \\
\hline Average & 11.0 & 14.5 & 9.1 & 10.6 & 10.5 & 12.7 \\
\hline Notes: & & & & & & \\
\hline $\begin{array}{l}\text { 1. New entrants cons } \\
\text { proxied by native }\end{array}$ & $\begin{array}{l}\text { t of immigrants having arrived in } \\
\text { orn persons aged } 30-39 \text {. }\end{array}$ & the previous ten years plus $n$ & orn persons having comp & heir education over the & years, & \\
\hline $\begin{array}{l}\text { 2. Persons in high-sk } \\
12,2 \text { and } 3 \text {. }\end{array}$ & jobs include managers (except $r$ & nanagers of small enterprise & rofessionals and associate pro & fessionals. These are ISCO co & es 11 & \\
\hline 3. Professional occup & ons refer to ISCO code 2. & & & & & \\
\hline
\end{tabular}

34. First of all, recent immigrants are more strongly represented in the employed population (14.5\%) than are all immigrants (11.0\%), illustrating the importance of immigration for employment growth over the last decade. However, the presence of immigrants in high-skill jobs overall (9.1\%) and in professional occupations in particular $(10.5 \%)$ is lower than their presence in employment as a whole. This reflects the generally lower skilled nature of migration to Europe and perhaps as well, the difficulty immigrants may experience in having their qualifications recognised by employers in the receiving countries.

35. What do the data tell us about the role of recent immigrants in high-skill jobs? The central result is that recent immigrants, that is, those who arrived in the ten years ending in 2006, are only slightly more represented in high-skill $(10.6 \%)$ and professional (12.7\%) occupations, respectively, than are all

5 There are significant numbers of persons still in tertiary education between the ages of 25 and 29 in northern Europe. 
employed immigrants $(9.1 \%$ and $10.6 \%)$. There are a number of notable exceptions to this general conclusion. They concern in particular Switzerland, Ireland, Luxembourg and the United Kingdom and to a lesser extent Austria (for professionals), Spain and the United States. That these countries are exceptions is hardly an accident. Ireland, Switzerland and the United Kingdom are all characterized by pro-active skilled migration programmes and national languages that are either widely used internationally (Ireland, United Kingdom, the United States) or are the national languages of large neighbours (the case of Switzerland); The latter is also true for Luxembourg and Austria. Spain has shown itself to be remarkably open to labour migration over the past decade ${ }^{6}$ and many immigrants have arrived there from countries in Latin America with which it shares a common language. The question of language is one that we will return to repeatedly in what follows, because it is a fundamental requirement for the recruitment and insertion of highly skilled migrants directly into jobs.

36. For other countries in Table 4, highly skilled migrants are no more prevalent among recent immigrants than they are among immigrants as a whole. Whether this reflects continuing restrictive or unsuccessful migration policies for the high-skilled, the nature of labour market demand or other factors is uncertain. As demographic change begins to exert a stronger influence on labour markets in coming years, it will be necessary for migration policies to adapt if highly skilled labour needs are to be addressed. As will be seen, the process is already under way.

\section{Key issues underlying policy choices}

37. Before presenting an overview of policies regarding highly skilled migration in OECD countries, it may be useful to specify a number of key issues underlying policy choices.

\section{Demand-versus supply-driven systems}

38. The first of these concerns the distinction between what might be termed demand as opposed to supply-driven migration systems. Demand-driven systems are those in which the initiative for the migration comes from the employer, who has a perceived need for a worker with a particular skill, who has generally identified such a worker (of foreign nationality), either abroad or in the country but without the right of residence and who makes a request to the immigration authorities for a work and residence permit for the future worker. The request is generally not entirely unconditional, that is, it may be subject to certain minimum qualification and wage and working conditions levels set by migration regulations, as well as to an employment test to ensure that no resident worker is available who would be able to fill the job vacancy adequately. Highly skilled workers recruited in this way are generally allowed to bring in their families and begin working upon arrival.

39. Supply-driven migration refers, among others, to situations in which a host country advertises its willingness to take applications for immigration directly from potential candidates, independently of a specific job offer, although the existence of such a job offer may be an element favouring a candidacy. The population of potentially eligible candidates is extremely large, but the number of acceptances and admissions is generally subject to a numerical limit. In the countries which practice this kind of recruitment, candidates are usually assessed for admission on the basis of characteristics deemed to facilitate labour market integration such as language proficiency, educational attainment, age, work experience, the presence of family in the host country and potentially, the existence of a job offer or the holding of an occupation considered to be in shortage. Each of the characteristics is assigned points and a certain minimum threshold must be exceeded in order for the candidate to be considered for admission.

6 Much of it, it is true, arrived in an irregular way. 
40. In existing regimes of this kind, successful candidates are given the right of permanent residence upon entry into the country and are allowed to come with their families with, it is expected, a settlement intention. Many arrive without employment and indeed, in some cases with little knowledge of the hostcountry language. They are, in a sense, "introduced" into the labour market of the host country to search for work, in the same way as other new entrants, but generally at a somewhat older age and potentially, with deficiencies in language proficiency or in other host-country-specific human capital, such as knowledge of job-search channels or contacts with potential employers. In addition, the candidate's formal qualifications and work experience may have been obtained in a country of which potential employers have limited knowledge.

41. A second type of supply-driven system is the free-circulation regime, in which potential labour migrants move to a country of destination to find work or to occupy a job for which they have been previously screened and hired. Although this is not regulated migration, it is not necessarily a zero-sum game for the countries involved, which can be more or less attractive as destination countries for highly skilled workers.

42. In practice, countries can combine elements of demand- and supply-driven systems in their migration policies, but there is generally an underlying orientation in favour of one or the other system.

\section{Temporary versus permanent migration}

43. A second fundamental distinction to retain is that between "temporary" and "permanent" migration. The terms here do not refer to the duration of the permit granted upon entry or even to the migrant's or employer's stay intention, which may be different from that stated in the permit or immigration application. They refer instead to the host-country's ex-ante view of the stay of the immigrant, as conveyed by the type and/or renewability of the permit. The permit duration granted may depend on the contract term of the job for which the migrant worker is being recruited but will be constrained by the durations provided for in the migration regulations.

44. All countries have temporary and permanent migration programmes, but only a few grant the right of permanent residence upon entry. In European countries, Japan and Korea, the right to permanent residence is granted only after a number of years on permits of temporary duration before the right of permanent residence is granted or the immigrant acquires the nationality of the host country. The temporary permits in these cases are generally renewed provided certain conditions continue to be satisfied, such as the holding of a job, or alternatively, unconditionally, especially after a certain number of years in the host country. It would be a distortion to claim that such migrants become "permanent" immigrants only when they receive the right of permanent residence. Indeed, some may spend their entire working lives, not to mention the rest of their lives, on permits of limited duration as residents of the host country. Despite the temporary nature of the permits they receive, immigrants with indefinitely renewable permits are generally deemed to be on a "permanent migration track" that involves eventual settlement.

45. Temporary migrants, on the other hand, are those who receive a permit which is either not renewable or renewable only on a limited basis. They include such persons as seasonal workers, international students, trainees, service providers, installers, performers, visiting researchers or academics, exchange visitors, etc. The possibility of remaining in the host country indefinitely usually is not allowed once the reason for the stay has passed. There is the possibility in some cases for the temporary migrant to "change status" and to apply for permanent-track status, as is sometimes done by international students, for example, at the end of their studies, but the changeover is not automatic. Most temporary migrants return or, at least, are expected to return to their countries of origin. 
46. In the current climate of international demand for highly skilled workers, it is undoubtedly the case that most countries would prefer not only to attract such workers but also to retain them permanently, while recognizing that a certain fraction of them may be highly mobile. However, the needs of employers may not always be for permanent workers, nor is this necessarily the wish of the immigrants themselves or, for that matter, of the governments of their countries of origin, for whom the loss of such workers may have a negative impact on economic development prospects.

\section{Selection of labour migrants}

47. Finally, the issue of the selection of immigrants is one that underlies all highly skilled discretionary labour migration. "Discretionary" here refers to the fact that for this type of migration governments can increase or reduce movements at will, unlike family or humanitarian migration, for which movements are subject to generally recognized human rights or international treaties or conventions.

48. Generally, immigrant selection is associated with points-based systems, in which the hostcountry authorities evaluate the suitability of migrants on the basis of certain criteria. However, employerdriven migration clearly also involves a selection of the immigrant, but by the employer to whom the hostcountry government can be considered to have delegated the task. The objective is to admit workers who satisfy immediate labour market demand and are guaranteed employment upon arrival.

\section{B. Current policies to manage labour migration of the highly skilled}

49. All OECD countries tend to facilitate the migration of highly skilled persons (see Annex Table for a summary). The means may range from allowing contract workers temporary entry into an otherwise closed labour market, to unrestricted access to enter the country permanently and to seek employment. The specific policy choices are conditioned by the underlying migration policy framework and objectives. The orientation is not necessarily towards an opening on all fronts.

\section{Employer-driven migration systems}

50. Most migration of the highly skilled in Europe and in Japan and Korea is employer-driven. This is also the mode of recruitment in the temporary regimes of the settlement countries. An employer must make a job offer before a high-skilled immigrant is allowed to enter the country for work purposes.

51. In most cases, employers are required to submit their request to a labour market test. The labour market test is meant to verify that the employer cannot fill the position locally. Characteristics of the labour market test vary, and reflect the role in matching workers with jobs played by public employment services. The length of time a job vacancy must be advertised varies across countries. Some countries, such as Austria, Czech Republic, Germany, Italy, Netherlands, Norway, Poland, Portugal, Spain, and Sweden, require employers to use the Public Employment Services to list the job opening. The Public Employment Services may consult unemployment and job vacancy lists and refer candidates to the employer, or may limit intervention to approving the request after a certain duration of public advertisement. In Spain, the job must be listed with the Public Employment Service for at least 15 work days; in Italy, the requirement is 21 days, while in the Czech Republic and Portugal it is 30 days. Employers may also be required to interview candidates sent by public employment services, as in Spain, which also requires employers to explain why they cannot hire local candidates. The requirement may be pro forma, as in Italy, where no application has ever been rejected due to a successful referral by the Public Employment Services.

52. Some countries allow employers to use alternative recruitment channels, and to demonstrate that they have attempted to fill the position. In the Canadian temporary regime, employers must generally advertise using private channels for 2-3 weeks. In Korea, the labour market test involves a listing of at least three days (newspaper), 7 days (public employment service) or one month (other means), following a 
check of unemployed Koreans with experience in the sector. In Ireland, the labour market test requires proof of advertisement, but only for jobs paying less than EUR 30000 per year and which are not on an exclusion list. New Zealand also requires employers of temporary workers to "make a genuine attempt" to recruit locally and to justify any refusal of local candidates. The United Kingdom also requires employers to have made an attempt to hire through advertisements.

53. France applies a discretionary consideration of the "added value" of hiring a foreign worker, expressed in terms of any new skills or resources represented by the candidate for France. Norway also considers the specific skills of foreign workers. Such discretionary criteria may be applied very restrictively, resulting in rejection of employer requests even where no local workers come forward to apply for a job. Some countries involve trade unions directly in the approval process: Denmark and Iceland both submit requests to the relevant trade union for confirmation of the job shortage and approval of the application.

54. In the United States, almost all categories of economic migration require an employment test. The H-1B programme, which provides temporary residence, is open to specialty occupations, primarily in information technology. There were $430000 \mathrm{H}-1 \mathrm{~B}$ visa holders in 2006. H-1B visa holders are also the primary source of applicants for employment-based permanent residence permits. The labour market test for the H-1B is quite limited: the job offer must be posted for 10 days at the workplace rather than publicly advertised, or simply circulated electronically among current employees. However, stricter conditions apply to so-called H-1B-dependent employers, those whose workforce relies heavily on H-1B visa holders. These employers must demonstrate that the worker has not displaced a native worker, and that "good faith" attempts at recruitment have been made.

55. The United States requires a permanent labour attestation for employment-based green cards as well. The Department of Labor must certify that there are no qualified local workers able, willing, qualified and available to accept the job at the prevailing wage for that occupation, and that employment of the foreigner will not adversely affect the wages and working conditions of similarly employed United States workers. Proof of attempts to recruit for the position is required.

56. Most countries requiring a labour market test have also foreseen a shortage occupation list to exempt employers from advertising positions where an obvious shortage exists. Often these shortage lists are drafted on a regional basis, generally through consultations among the Public Employment Services, employers and trade unions. Canada uses a provincial "Occupations under pressure" list to exempt employers from the labour market test. Finland uses a regional shortage list established annually through consultations with social partners. France uses vacancy data to determine two shortage lists: the first, including high-skill occupations, establishes eligibility for third-country nationals; a second, longer, list includes some lower skill occupations as well and determines eligibility for citizens of new EU countries. German legislation allows for a shortage list, but none has been used so far. Ireland has both a shortage list and an "ineligible occupation list" for which no authorisation will be granted. New Zealand has an "Immediate Skill Shortage List". Spain's regional shortage list, the Catalogue of Hard-to-Fill Positions, is revised every three months for each province.

57. The United Kingdom is currently defining the methodology for its shortage list, which has been delegated to the Migration Advisory Committee (MAC). In addition to applying skill definitions, the MAC will also look at wages, vacancies and unemployment, recruitment and benefit changes, and the possibility to draw on resident workers through greater labour force participation or training initiatives. The Shortage Occupation List will exempt the employer from the Resident Labour Market test and will, along with English-language skills, ensure approval of the employer request. 
58. The United States uses a shortage list ("Schedule A") for exemption from labour certification for permanent residence under its employer-driven EB2 and EB3 visa programs. Compared with other countries, the list is short: the sole current shortage occupations are physical therapists, nurses, and specialised "arts and sciences".

59. The specificity of shortage lists varies. Broadly speaking, the definitions are sufficiently precise to cover the likely job description while narrow enough to reflect professional certification systems. Spain, Canada and the United Kingdom define their shortages using 4-digit degrees of specificity. France uses 5-digit categories, while New Zealand's "Immediate Skills Shortage List" and Australia's MODL apply a 6-digit occupation category. The objective in most countries which do not use codes is to define the shortage occupation clearly and sufficiently narrowly.

60. No labour market test is in place in Japan or Australia, although recruitment is limited to specific professions and subject to proof of qualifications, wages, and/or experience. In Japan, for Engineers and Specialists in Humanities, a college degree or 10 years experience in the occupation (including upper secondary and specialised education), as well as proof of prevailing salary, is necessary to qualify.

61. Beyond the labour market test, a general quota or cap may be applied (see Table in Annex). Australia and the United States apply caps to their permanent programmes. Norway applies a cap to its skilled programme but allows further entry following a labour market test. Italy applies a cap but includes a number of exemptions. The cap is not the only way to reduce entry: a strict application of a labour market test may be more effective in reducing entries.

\section{Immigrant-driven migration}

62. Immigration of the high-skilled without a job offer can be the result of selection through a pointsbased system, of movement under a free-circulation regime, or of entry through other migration categories.

\section{- Point systems}

63. High-skilled immigrants may, under certain circumstances, enter the United Kingdom, Canada, Australia, New Zealand and Denmark without a job offer. Eligibility is based on the characteristics of the immigrant - the human resources they represent - and is determined according to a points-based system. The United Kingdom's Tier 1 for highly skilled migrants is the latest example (see Box 1). The permit granted under Tier 1 is for an initial period of three years. After the first renewal, the immigrant becomes eligible for permanent residence after five years of residence.

64. Denmark offers a job-search visa it calls a "Green Card", which allows high-skilled immigrants to come to Denmark to search for a job. Qualification is through a points system, which considers education, language skills (both in a Scandinavian language and/or in English or German), experience, age, prior wages, and professions on the Danish Job Card Scheme shortage list. Green-card holders have six months to find a job on the Job Card Scheme shortage list (generally masters-level occupations) or a job paying at least DKK 463000 (EUR 63 000) annually. 


\section{Box 1. A comparison of the Australian and United Kingdom points systems}

The new points-based management system (PBS) in the United Kingdom is modelled to some extent on the Australian General Skilled Migration (GSM) points test. There are significant differences, however, notably that the GSM grants permits of unlimited duration whereas PBS permits (Tiers 1 and 2) are always temporary, even if the intention of the migrant may be permanent settlement. Tier 2 in particular can include some movements of workers arriving for temporary assignments.

The GSM programme is designed to admit skilled people and their families as immigrants to Australia. Tier 1 in the United Kingdom has replaced the former Highly Skilled Migrant Programme. It is designed to allow highly skilled potential migrants to apply for entry to the United Kingdom without having a job offer; in this it differs from the new Tier 2 which is also points-based but will require a job offer and be less selective.

Under Tier 1, 95 points must be accumulated. Of these, 10 come from a compulsory language test to prove that the potential migrant speaks English to the required standard and 10 from demonstrating that he/she possesses sufficient funds to be self-supporting in the United Kingdom. Anyone unable to pass the language and sufficient means tests cannot qualify. A further 75 points are required from four attributes: age, qualifications, previous earnings and United Kingdom experience. In the GSM, 120 points are required to pass, and a level of 100 to enter the pool for possible future consideration.

The GSM points allocation covers a more comprehensive range of attributes which partly overlaps with that in the PBS but also with major differences. Australia specifies a target level of GSM migrants accepted each year whereas there is no cap or quota for Tier 1 migrants in the United Kingdom. Tier 1, however, is more highly selective than the Australian GSP programme. Despite devolution to Assemblies in Scotland, Wales and Northern Ireland, immigration policy remains in the hands of the central government. In consequence, there is no "regional" component in the United Kingdom comparable with Designated Area Sponsorship or State/Territory Nomination in Australia, for example.

Perhaps the most important difference between the two systems is that the United Kingdom Tier 1 emphasises past earnings as being the best guide to likely future labour market success. This result is based on experiences with the Highly Skilled Migrant Programme. Previous salary is measured relative to rates in the country in which it was earned. In contrast, in the Australian GSM, points for shortage occupations and occupations on a skilled occupation list, in addition to work experience and other factors, are taken as predictors for successful labour market integration. For the new Tier 2 in the United Kingdom, points will be allocated for shortage occupations; however, the final points list for Tier 2 workers in the United Kingdom is not yet finalised.

65. Canada, Australia, New Zealand and the United States also all offer permanent residence without a job offer to the highly qualified subject to certain criteria. In the United States, the EB1 visa has a very restrictive scope for non-employer-driven migration, and grants permanent residence only to "persons of extraordinary ability" of national or international renown. Other countries use "human resource" criteria, based on points, to approve immigration by the highly skilled. While employment is not obligatory, a prior job offer counts for additional points in Canada, Australia and New Zealand. New Zealand applies a stricter review to applicants without a job offer, for whom permanent residence is probationary for the first two years.

66. The parameters considered in the points system are similar across countries: age, language skills, profession and education, professional and educational experience in the country (Table 5). Younger applicants receive more points. Language skills are required, although formal certification may be substituted with proof of ability. Professions on shortage lists or for which there is local demand grant more points. Most systems are designed to attribute points to higher education and exclude those with no education, although non-academic skills in a shortage profession may be sufficient, along with other factors, to qualify. An occupation on the shortage list provides additional points in Canada (for temporary workers), Australia and New Zealand, as does experience in the country, whether through work or study. A spouse can add points to an application under certain circumstances in Canada, Australia and New Zealand, and family ties in the country can help an application. 
Table 5. Points attributed under different points systems for permanent residence in selected countries, $2008^{7}$

\begin{tabular}{|c|c|c|c|c|}
\hline Characteristic & UK/HSMP & Australia/GSM & $\begin{array}{l}\text { Canada Skilled } \\
\text { Worker }\end{array}$ & $\begin{array}{l}\text { New Zealand } \\
\text { Skilled } \\
\text { Worker }\end{array}$ \\
\hline Language ability & 10 & $15-25$ & $0-24(16+8)$ & Obligatory \\
\hline Sufficient funds for initial period & 10 & & Obligatory & \\
\hline Age (younger = more points) & $5-20$ & $15-30$ & $0-10$ & $5-30$ \\
\hline Qualifications/Academic & $30-50$ & $5-25$ & $0-25$ & $50-55$ \\
\hline Skilled Occupation & & $40-60$ & & \\
\hline Work experience in occupation & & $5-10$ & $0-21$ & $10-30$ \\
\hline Recent earnings & $5-45$ & & & \\
\hline Spouse/partner skills & & 5 & $0-10$ & 50 \\
\hline Shortage occupation & & $15-20$ & & 20 \\
\hline In-country work experience & 5 & 10 & $0-10$ & $5-15$ \\
\hline Regional Study & & 5 & & \\
\hline Designated area sponsorship & & 25 & & \\
\hline Job Offer & & & $0-10$ & $50-60$ \\
\hline State/Territory of settlement & & 10 & & 10 \\
\hline Professional Language skill & & 5 & & \\
\hline Number required & 95 & $\begin{array}{c}100 \text { - } 120 \\
\text { Pool - Pass }\end{array}$ & 67 & $\begin{array}{c}100-140 \\
\text { Pool - Pass }\end{array}$ \\
\hline
\end{tabular}

Source: Government authorities. Some categories are conflated and others are excluded.

\section{Special migration schemes for highly skilled workers}

\section{International Students}

67. Over the past ten years, the number of international students has risen steadily, and this trend has accelerated since the beginning of the millennium. Table 6 shows the inflows of international students into selected OECD countries. While there has been an increase in all countries, it has been particularly pronounced in the United Kingdom, Australia, New Zealand, Sweden and Norway, where inflows have doubled since 1999.

7 The number of points awarded for different values of each characteristic varies across countries. In Australia and the United Kingdom, for example, a minimum level of language proficiency is required, whereas there is no such cutoff in Canada. The maximum age beyond which no points are awarded also varies across countries. In Australia immigrants over 45 are excluded from consideration entirely. 
Table 6. Inflows of international students into selected OECD countries ('000s)

\begin{tabular}{lrrrrrrrrrrr} 
Country & 1996 & $\mathbf{1 9 9 7}$ & $\mathbf{1 9 9 8}$ & $\mathbf{1 9 9 9}$ & $\mathbf{2 0 0 0}$ & $\mathbf{2 0 0 1}$ & $\mathbf{2 0 0 2}$ & $\mathbf{2 0 0 3}$ & $\mathbf{2 0 0 4}$ & $\mathbf{2 0 0 5}$ & $\mathbf{2 0 0 6}$ \\
\hline United States &.. &.. &.. &.. & 284 & 293 & 234 & 216 & 219 & 238 & 274 \\
United Kingdom & 48 & 71 & 67 & 68 & 76 & 70 & 99 & 118 & 128 & 117 & 137 \\
Australia &.. &.. &.. & 67 & 74 & 86 & 98 & 110 & 115 & 117 & 129 \\
New Zealand &.. &.. & 22 & 29 & 46 & 74 & 88 & 87 & 78 & 69 & 67 \\
Canada & 40 & 42 & 40 & 50 & 60 & 68 & 64 & 58 & 55 & 57 & 62 \\
Germany & 29 & 31 & 35 & 40 & 46 & 53 & 58 & 60 & 58 & 56 & 54 \\
France &.. &.. &.. & 25 & 36 & 40 & 55 & 52 & 55 & 46 & 47 \\
Japan &.. & 24 & 28 & 34 & 42 & 47 & 51 & 53 & 37 & 41 & 46 \\
Spain &.. &.. & 22 & 27 & 29 & 29 & 24 & 30 & 36 & 31 & 33 \\
Italy &.. &.. &.. &.. &.. & 27 & 31 & 32 & 31 & 32 & 33 \\
Sweden & 3 & 4 & 4 & 5 & 5 & 6 & 7 & 8 & 10 & 11 & 11 \\
Netherlands & 4 & 6 & 6 & 6 & 6 & 8 & 9 & 9 & 10 & 10 & 9 \\
Mexico & 6 & 10 & 11 & 11 & 6 & 9 & 7 & 6 & 5 & 5 & 6 \\
Denmark &.. &.. &.. &.. & 4 & 4 & 5 & 6 & 6 & 7 & 5 \\
Norway &.. &.. &.. &.. & 2 & 2 & 3 & 3 & 4 & 4 & 5 \\
Portugal &.. &.. &.. & 3 & 4 & 4 & 4 & 4 & 3 & 4 & 5 \\
Source: OECD Database on international migration. & & & & & & & & &
\end{tabular}

Note: Data for the United Kingdom, Norway, Sweden, and Switzerland include EU students. For the other European countries they refer to third-country students only.

68. International student policy has now become a tool in the international competition for high-level skills. There are two main channels by which foreign students are used as a talent pool - by allowing them to work during their studies, and by allowing status changes after their studies.

Working opportunities during study

69. Most countries now allow students to work during studies, generally between 20 and 24 hours a week during term. Some countries, for example Japan and the United States, require students to apply for specific authorisation. Others grant it automatically, but with certain restrictions. In Finland, international students have the same right to work as Finnish students while studying, although they must have their own health insurance. Since April 2008 international students in Australia also have work rights when granted their initial student visa.

70. Student employment may not necessarily help in finding work later, but it does grant some familiarity with the local labour market and practices. Work within one's field may be particularly important for increasing the likelihood of finding employment after graduation. However, quite often student work is in less skilled occupations, which nevertheless provides students with financing and first contact with the labour market, and therefore enhances the probability to remain in the country. In the USA, most international (F-1 visa) students in a full-time degree programs are permitted to work on campus up to 20 hours per week during the school year and may work full-time during vacations. After completing one year of study they may also apply for Curricular Practical Training (CPT) to gain work experience in their field of study while being a full time student. Graduate teaching assistants, in particular, are a welcome addition to the staff of many undergraduate programmes. After completing their undergraduate or graduate degree, foreign students may also take advantage of Optional Practical Training (OPT) for up to one year as a full-time employee.

71. Particularly in European OECD countries, provisions for the labour market access of international students have been liberalised significantly over the past few years. Since 2007, international 
students in France wishing to work while studying do not need work authorisation, provided employment does not exceed $60 \%$ of their time in any one year.

72. Norway has also made it easier for international students to access the labour market during their studies. Recent changes in legislation allow students a general part-time ( 20 hours per week) work permit an offer of employment is no longer a prerequisite. Further measures facilitating the transition to work after completing education are being considered. Denmark allows only 15 hours per week during term, but allows full-time employment during the summer.

Status changes of foreign graduates to become highly-skilled migrants

73. A large number of OECD countries have established pathways for foreign graduates to become labour migrants. In OECD countries with a long-standing selection policy, i.e. Australia, Canada and New Zealand, foreign graduates have emerged as one of the key sources for highly-skilled migration. In Australia, in 2005-2006, more than 17000 foreign graduates became skilled migrants, accounting for almost $20 \%$ of entries under this category. ${ }^{8}$

74. In European OECD countries, possibilities for such status changes also exist, but are still a rather limited pathway. In Germany, for example, in 2006 less than 2000 of the about 14500 foreign graduates from non-EU countries took advantage of the possibility to remain in the country to look for work. Already with the immigration law of 2005, foreign graduates from German universities could stay in Germany for up to one year to find a job. Since November 2007, foreign graduates of German universities are also exempt from the labour market test if their employment corresponds to their studies.

75. In 2006, the Netherlands took steps to enlarge the residence opportunities for international students after the completion of their studies. The Dutch government grants foreign students the opportunity to stay in the Netherlands and to seek high-skilled work for up to three months after graduation. If they find highly skilled employment, they receive a residence permit; otherwise, they must leave the Netherlands. Austria similarly allows international students graduating from Austrian universities to change their status to permanent residents if they find highly skilled work.

76. Policy towards international students and the labour market is undergoing fundamental change in the United Kingdom. In May 2007, the International Graduate Scheme (IGS) was launched to replace the more limited Science and Engineering Graduate Scheme (SEGS). This is a precursor to the Tier 1 Post Study category, and is a response to the drive in a number of countries to compete for the retention of growing numbers of international students. The IGS enables all non-EEA students who have successfully completed their degree (regardless of discipline) at an approved higher education institution in the United Kingdom to remain in the country for up to 12 months and compete for work. The future Post Study category is likely to extend this period to two years, bringing it into line with the Fresh Talent Working in Scotland Scheme (FTWSS), and to restrict access to international graduates with at least a lower second class (2.2) degree.

77. Ireland has moved in the same direction. In April 2007, the Third Level Graduate Scheme was implemented, allowing non-EEA graduates from Irish universities to remain in Ireland for six months after graduation to find employment and apply for a work permit or green card. During the six-month period they are allowed to work. The "six-month" rule applies also in Finland where the policy is to encourage the immigration of students and researchers. An amendment to the Aliens Act in 2006 eased conditions for entry of non-EEA students into the Finnish labour market. Such graduates can now obtain a work permit to search for a job for up to six months and a residence permit for job search for 10 months.

8 The figure is even higher if only primary applicants are considered. 
78. In France, new legislation in 2006 was designed to encourage Masters graduates of the highest ability to stay on and find employment which "directly or indirectly benefits the economic development of France and the student's home country". These so-called 'high-potential' students receive a provisional non-renewable authorisation to stay for six months, to seek a job in their field of study. After six months, if the graduate has or is promised a job paying at least $150 \%$ the minimum wage, a temporary permit is granted without requiring a labour market test. Students who do not hold a Masters degree or who have found work in a different field from the studies, or one which pays too little, are allowed to apply under the general permit system.

79. Targeting of particular types of skill is seen in the policy measures of some other countries. A government committee in Sweden has proposed that it should be made easier for foreign students who have found a job in Sweden to stay in the country and work after finishing their studies. Encouraging them to stay is also policy in the Slovak Republic where international students and researchers are now allowed to stay for up to 90 days without a temporary residence permit.

80. Canada seeks to maintain a competitive edge in attracting international students, and has expanded its Post-Graduation Work Permit Programme to grant 3-year permits to graduating students. They are no longer required to work in their field of study nor does their region of employment affect the duration of the permit. The field of employment does, however, affect their change to permanent resident status, since only higher-skill fields (NOC O, A and B) provide access to permanent status (1 year).

81. In other countries, changes in regulations relating to international students are making it easier for them to obtain permanent residence permits. In the Czech Republic, in 2006, the Alien Residence Act was amended to encompass various EU Directives including one relating to the status of students. Other amendments relate to easier entry for researchers.

82. The United States offers the opportunity to change status to different groups of foreign students. The principal programme consists in a reserve of $20000 \mathrm{H}-1 \mathrm{~B}$ visas for foreign graduates at the Masters level. In general, students can stay six to twelve months after graduation for professional training. The United States does not allow change of status to students who requested authorisation to work during the summer while studying.

\section{Intra-corporate transfers}

83. One way that multinational firms can hire high-skilled foreign workers without the constraints placed on immigration is to use intra-company transfers from within the same company. An intra-company transfer must have been employed within the company in a foreign country - usually for at least 12 months before the transfer - and must come to perform executive or specialised tasks. Specific job requirements are detailed, since this relatively open channel could be abused to bring in less qualified workers outside a quota or without a labour market test. The job description of an executive - management, supervision, and discretion in decision making - can also be supplemented by additional requirements. Ireland, for example, also requires a minimum salary (EUR 40000 ). Permits of stay are generally granted for one or two years and subject to review and renewal. Canada and the United States have similar requirements for their intracompany transfers, limiting stay to seven years for executives and five years for specialised workers. Italy and Ireland allow transferees to stay for up to five years. Japan grants renewable permits for one or three years. The United States is the principal recipient of intra-company transfer flows (Table 7; the stock of intra-company transferees working in the United States in 2006 was 320 000. The United Kingdom also hosts a significant number of intra-company transferees: the stock in 2006 exceeded 43000.

84. In most cases, intra-company transfers cannot apply for permanent residence or automatically change status to a work permit, although they are eligible to use the same channels and their experience in 
the country may help their application. Korea allows intra-company transferees to apply for permanent residence after five years.

Table 7. Flows of intra-company transfers, selected OECD countries, 2000-2006

$\begin{array}{lrrrrrrr}\text { Country } & \mathbf{2 0 0 0} & \mathbf{2 0 0 1} & \mathbf{2 0 0 2} & \mathbf{2 0 0 3} & \mathbf{2 0 0 4} & \mathbf{2 0 0 5} & \mathbf{2 0 0 6} \\ \text { Austria } & 163 & . . & . . & 168 & 172 & 96 & 196 \\ \text { Canada } & 1634 & 1759 & 3028 & 3800 & 4168 & 4529 & 5703 \\ \text { Switzerland } & . . & . . & . . & 14366 & 7514 & 1849 & 3968 \\ \text { Germany } & 1296 & 2023 & 1903 & 2131 & 2322 & 2530 & 2757 \\ \text { Japan } & 3876 & 3463 & 2900 & 3421 & 3550 & 4184 & 5564 \\ \text { Korea } & 10031 & 9154 & 8667 & 7846 & 8508 & 8369 & 8126 \\ \text { United States } & 54963 & 59384 & 57721 & 57245 & 62700 & 65458 & 72613\end{array}$

Source: OECD Database on International Migration.

Note : Flows for European countries do not include movements of EU citizens except Switzerland.

\section{Free circulation}

85. In addition to high-skilled migration programmes designed to admit immigrants, free circulation may be a channel for movement by the highly skilled. The largest free-movement area in the OECD is in Western Europe, where movement for employment is largely unrestricted for citizens of the older EU member countries and Switzerland, Norway and Iceland. Some transitional measures in some countries are in place for citizens of the EU countries which joined in 2004, and additional measures are applied to citizens of Romania and Bulgaria.

86. Free-circulation regimes do not privilege the higher skilled over those with less education, but they do facilitate recruitment by reducing bureaucratic obstacles, lowering costs and allowing for direct contact between employers and employees. The United Kingdom, which received the largest freemovement flows following EU expansion in $2004^{9}$, saw largely migration into lesser skilled jobs. Nonetheless, $2220(1.2 \%)$ of the A8 workers registering under the Worker Registration Scheme in 2005 were professionals, and $18500(9.5 \%)$ were managers and senior officials.

\section{Derived / spillover migration (family, humanitarian, ethnic)}

87. The programmes for highly skilled migrants covered in the Annex table assess the so-called "primary migrant", the lead person in the family, for immigration under the specified high-skilled programme. Economic migration of this sort, however, is often only a fraction of the total flow of immigration into many OECD countries. Other forms of migration include accompanying family members of labour migrants, as well as persons coming to join an already established family member; humanitarian migrants (convention and resettled refugees, protected persons); ethnic migrants; and generic labour migrants. Persons in these groups may also contribute to high-skilled migration.

88. Accompanying family members are explicitly accounted for in the point-systems in Canada, Australia and New Zealand, which attribute additional points according to the skills, qualifications and experience of accompanying spouses.

9 On a per-capita basis, movements to Ireland by citizens of the new member countries were by far the most significant. 
89. Family reunification usually grants labour market access to entering family members. Labour force participation rates of highly educated family migrants tend to converge towards the average over time, especially for better educated family migrants (OECD 2007b).

90. Humanitarian migration has generally presented great challenges for labour market integration, including for highly qualified migrants, who are especially penalised by the difficulty in obtaining the recognition of foreign qualifications and in obtaining certification in the new country. Nonetheless, the average educational profile of some refugee populations has been relatively high.

91. Ethnic migration programmes aim to resettle linguistically, culturally or ethnically related peoples in the host country. Large ethnic migration programmes took place in the 1990s in Germany and Greece, primarily from the former Soviet Union. In the former case, many immigrants were highly educated, although their employment outcomes have not been especially favourable (Frick, 2004). Japan has used its ethnic migration programme for low-skilled work by ethnic Japanese from South America, rather than skilled migration. According to 2000 Census data, their actual skills appear to be underutilised: about $17 \%$ of the Brazilians of Japanese origin working in Japan were tertiary educated, but only $5 \%$ of these were in professional occupations. Finland, similarly, has seen its ethnic return programme for Karelian and Ingrian Finns as primarily a source of labour for less skilled positions, even if the candidates are generally well-educated (albeit under the Soviet system).

\section{Critical issues in implementing migration policy for the highly skilled}

92. The critical issues in implementing migration policies for the highly skilled developed in this section were drawn from a review of policy priorities and strategies in ten OECD countries. Main policy choices are identified as well as key determinants for the labour market outcomes such as qualifications, experience and language.

\section{Comparing policy priorities with policy choices in ten countries}

93. The choices made in each country are subject to fundamental priorities. A review of policy priorities and strategies in ten OECD countries (Table 8) reveals how policy for facilitating international migration of the highly skilled varies. While all countries allow migration by the high skilled, it is not enough to simply allow high-skilled people to enter: they must also wish to do so. Some factors are more important than others in determining the attractiveness of a country for immigration: wage levels, quality of life, existing communities, language, likelihood of extension and permanent residency, and access to the labour market for family members. English-speaking countries, as noted, have been able to count on a vast pool of candidates, and relatively high wages in the United States, Canada, and Australia have ensured that demand has been high enough to meet their targets. The United Kingdom is revising its system without changing its fundamental approach to high-skilled migration, which it should continue to attract as needed. For the United States, the priority is not reaching a target but placing limits on the total inflows. Employers are therefore prevented from hiring as many foreign high-skilled workers as they would like.

94. For these countries, an active immigration policy for the high skilled does not require special recruitment efforts. An active policy may even seem superfluous; in the United States, administrative obstacles and high processing fees have not deterred applicants or employers.

95. Other countries, such as Germany, the Netherlands and France, have recently reformed their immigration policy to restrict immigration, while still leaving a margin for employers to hire high-skilled workers. Germany and the Netherlands both set high thresholds for eligibility - these thresholds are the topic of negotiation with employers - beyond which international recruitment is exempt from the restrictive conditions imposed on ordinary labour migrants. Germany's programme has not led to increased 
flows, as most of its participants were already in the country. A broad overview of recent developments in migration policy in Germany for the highly skilled is given in Box 2.

\section{Box 2. Skilled labour shortages, policy options, and migration of the highly skilled - the case of Germany}

In spite of economic recovery - driven by exports - and the onset of population ageing, permanent-type immigration to Germany has declined in recent years. The German government's priority is to meet the increasing demand for skilled workers primarily by enhancing training of domestic workers, increasing the labour force participation of women and older people, and through the qualification of immigrants already living in Germany, including the second generation. The focus on domestic mobilisation has to be seen in the context of relatively high unemployment among highly-qualified immigrants on the one hand, and non-negligible emigration on the other. In 2005 , unemployment of highly-qualified immigrants was around $13 \%$, almost three times higher than among highqualified native-born. In addition, there have been some signs of growing emigration, in particular of highly-qualified Germans. While both the scale and the nature of this emigration remain unclear, the public debate has included concern over a "brain drain".

The new immigration law of 2005 took a number of measures to promote high-skilled migration to Germany. Foreign students may now change status after graduation. Some groups of highly-skilled specialists are granted permanent residence upon entry: researchers and university teachers, and employees earning at least EUR 85000 . In 2005 and 2006, only slightly more than 1100 persons received a permanent residence permit on these grounds; the vast majority were already in Germany on other permits. Although there are other entry channels for highly-skilled migrants, including through the regular work permit route, this low number is often publicised as the number of highlyskilled immigrants entering the country. Germany is also one of the few EU-15 members to maintain strict restrictions on immigration of nationals from the new EU member states.

In 2007, signs of skilled labour shortages in certain regions and occupations intensified, particularly in the metal and electronics sectors. Because of this, skilled labour shortages became a central issue on the agenda of the German government's cabinet meeting in Meseberg in August 2007. The cabinet decided to reinforce its efforts to activate the domestic labour force potential through strengthened training and qualification measures; and to take additional measures for eliminating shortages in certain sectors which were viewed as difficult to cover domestically by a careful opening for further labour immigration.

As a consequence, a new ordinance on the access of foreign university graduates to the labour market has been enforced. The labour market test is no longer applied for foreign graduates from German universities and universities of applied science, regardless of the subjects of their studies, if they want to take up employment in their field. The labour market has also been opened for mechanical engineers, vehicle engineers and electrical engineers from the ten central and east European EU Member States still subject to transitional rules limiting access to the German labour market.

To be able to better react to labour shortages and to create a reliable basis for decisions on labour immigration, the German government also plans to systematically monitor the need for skilled workers. The experiences of other OECD countries with labour-market related immigration management are also considered in this context.

96. The Netherlands considers its programme a success, although participants could have used the more cumbersome standard procedure - and some employers still do, perhaps because it does not grant portability to the employee. In France, the policy has met the demands of employers, who have not made great recourse to foreign labour, preferring French-trained workers and taking full advantage of free movement within the EU.

97. Norway has reduced the burden on employers of high-skilled workers but faces limits on its ability to attract workers due to language problems and relatively low net (i.e. after-tax) income compared with English-speaking countries. While it has allowed foreign students to stay on to work, marriage has long been a more important factor in keeping international students.

98. The Czech Republic has simplified its bureaucratic procedures for high-skilled foreigners with a job offer, but it has not been able to attract many new workers. Wages are relatively low and administrative procedures, for which high-skilled workers enjoy few facilitations during their temporary-permit phase, are 
burdensome. An information campaign in some prospective recruitment countries failed to attract successful job seekers.

99. Japan leaves a limited option for immigration of the high skilled in what is otherwise a closed labour market. Since it requires college or ten years experience for professional and technical workers, as well as certain salary levels, qualification is difficult. Japanese employers, however, do make use of intracompany transfers; there were more than 14000 working in Japan in 2006.

100. Some of the above countries have modified their policies in an attempt to attract high-skilled workers. However, upon review, most of these policies are not so much designed to attract workers as to reduce the obstacles to their immigration. In fact, none of the policies adopted actually supports immigration of the high skilled: there are no subsidies, no facilitation of the recognition of qualifications; no special job listings abroad. Given the value of high-skilled workers, it is assumed that employers will pay whatever costs are necessary to obtain a skilled worker, and that the promise of a high salary is incentive enough for an aspirant immigrant to pay the certification and visa fees necessary for migration.

101. An active immigration policy includes job fairs (as run by Australia and the United Kingdom), bilateral agreements with source countries, multilingual employment offer portals (in fact, part of the Czech strategy), and assistance in administrative procedures both during and after entry. What is surprising in the review above is that "active" policy is generally defined as simply creating exemptions from the restrictions on labour migration applied across-the-board. As shortages increase, truly "active" policies for the high skilled may start to be adopted, especially outside the benchmark high-wage and English-speaking countries.

Table 8. Country comparison: Policy priorities and strategies for high-skilled migration

\begin{tabular}{|c|c|c|c|}
\hline Country & Policy background & Strategy & $\begin{array}{c}\text { Outcome and issues to } \\
\text { monitor }\end{array}$ \\
\hline Canada & $\begin{array}{l}\text { - Immigration as element of overall } \\
\text { development strategy, with target } \\
\text { entry levels } \\
\text { - Immigration to meet skills } \\
\text { shortages }\end{array}$ & $\begin{array}{l}\text { - Selection of higher skilled } \\
\text { immigrants and their spouses for } \\
\text { permanent migration } \\
\text { - Facilitation for international } \\
\text { students }\end{array}$ & $\begin{array}{l}\text { - Targets met. } \\
\text { - Some problems with } \\
\text { overskilling of those who } \\
\text { arrive without a job. }\end{array}$ \\
\hline Australia & $\begin{array}{l}\text { - Immigration as element of overall } \\
\text { development strategy, with target } \\
\text { entry levels } \\
\text { - Immigration to meet skills } \\
\text { shortages }\end{array}$ & $\begin{array}{l}\text { - Selection of higher skilled } \\
\text { immigrants and their spouses for } \\
\text { permanent migration } \\
\text { - Facilitation for international } \\
\text { students }\end{array}$ & $\begin{array}{l}\text { - } \text { Targets met. } \\
\text { - Some question of } \\
\text { language skills for } \\
\text { international students }\end{array}$ \\
\hline United States & $\begin{array}{l}\text { - Protect native workers while } \\
\text { meeting employer needs } \\
\text { - Prevent low-skilled immigration } \\
\text { and limit immigration in general }\end{array}$ & $\begin{array}{l}\text { - Quotas for most high-skilled } \\
\text { categories } \\
\text { - Job offer essential } \\
\text { - Large temporary programme } \\
\text { - Little facilitation for international } \\
\text { students }\end{array}$ & $\begin{array}{l}\text { - Programmes } \\
\text { oversubscribed, with long } \\
\text { waiting lists } \\
\text { - Recourse to alternative } \\
\text { visas (exchange, IC } \\
\text { Transfers, etc.) }\end{array}$ \\
\hline $\begin{array}{l}\text { United } \\
\text { Kingdom }\end{array}$ & $\begin{array}{l}\text { - Rely on free movement as much } \\
\text { as possible } \\
\text { - Allow highest skilled to enter } \\
\text { while limiting immigration of less } \\
\text { skilled }\end{array}$ & $\begin{array}{l}\text { - Points-system for migration by } \\
\text { highest skilled; no quota } \\
\text { - Shortage list for high skilled } \\
\text { employees sought } \\
\text { - Access for international students to } \\
\text { above }\end{array}$ & $\begin{array}{l}\text { - New system yet to be } \\
\text { evaluated }\end{array}$ \\
\hline France & $\begin{array}{l}\text { - Protect native workers while } \\
\text { meeting employer needs } \\
\text { - Increase "economic migration" }\end{array}$ & $\begin{array}{l}\text { - Strict labour market test and } \\
\text { occupation list }\end{array}$ & - Limited immigration \\
\hline Netherlands & $\begin{array}{l}\text { - Reduce immigration by people } \\
\text { with few skills and little Dutch } \\
\text { language }\end{array}$ & $\begin{array}{l}\text { - Exemptions from strict language } \\
\text { and labour market test for high- } \\
\text { skill, high salary }\end{array}$ & $\begin{array}{l}\text { - Satisfactory use of "high- } \\
\text { skilled" permit, meets } \\
\text { expectations }\end{array}$ \\
\hline
\end{tabular}


DELSA/ELSA/WD/SEM(2009)5

\begin{tabular}{|c|c|c|c|}
\hline Country & Policy background & Strategy & $\begin{array}{c}\text { Outcome and issues to } \\
\text { monitor }\end{array}$ \\
\hline & & & $\begin{array}{l}\text { - some employers still use } \\
\text { standard work permit }\end{array}$ \\
\hline Germany & $\begin{array}{l}\text { - Limit immigration while allowing } \\
\text { high skilled to enter } \\
\text { - Compete with other destinations } \\
\text { for the highest skilled }\end{array}$ & $\begin{array}{l}\text { - Permanent residence for very high } \\
\text { skill and high-paid foreigners } \\
\text { - Strict conditions for others } \\
\text { - Some possibility for former } \\
\text { students }\end{array}$ & $\begin{array}{l}\text { - Limited immigration, } \\
\text { mostly change of status of } \\
\text { students, others. } \\
\text { - Flows fall short of } \\
\text { expectations }\end{array}$ \\
\hline Norway & $\begin{array}{l}\text { - Protect native workers while } \\
\text { meeting employer needs } \\
\text { - Free movement supposed to meet } \\
\text { many labour needs }\end{array}$ & $\begin{array}{l}\text { Quotas for most high-skilled } \\
\text { categories } \\
\text { - Job offer essential }\end{array}$ & - Quota undersubscribed \\
\hline Japan & $\begin{array}{l}\text { - Accept high-skilled migration } \\
\text { while maintaining limit on low- } \\
\text { skilled immigration }\end{array}$ & $\begin{array}{l}\text { - Strict definition of skilled positions } \\
\text { - Allow foreign students to seek } \\
\text { work }\end{array}$ & $\begin{array}{l}\text { - Little high-skilled } \\
\text { migration despite } \\
\text { openness } \\
\text { - Some students remain for } \\
\text { employment }\end{array}$ \\
\hline Czech Republic & $\begin{array}{l}\text { - Facilitate employment of high- } \\
\text { skilled foreigners by Czech } \\
\text { employers }\end{array}$ & $\begin{array}{l}\text { Accelerate access to permanent } \\
\text { residence for highly qualified } \\
\text { foreign workers }\end{array}$ & $\begin{array}{l}\text { - Most beneficiaries are } \\
\text { already in Czech Republic } \\
\text { - Flows less than hoped }\end{array}$ \\
\hline
\end{tabular}

\section{Policy Choices}

102. The foregoing has outlined existing policies in a number of OECD countries related to highly skilled migration. They have brought to the fore some commonalities across countries but also some differences. The purpose of this section is to examine more closely the issues underlying these differences, with a view to better understanding the current evolution of migration policy with respect to the highly skilled. The issues concerned are the differences between demand and supply-driven migration systems, the decision to impose numeric limits, the choice between labour market tests and shortage lists, between temporary and permanent stay, and the treatment of students.

\section{Demand-and supply-driven systems: benefits and disadvantages}

103. In recent decades, European countries have been reluctant to consider admissions of labour migrants if they do not have prior job offers. Although such arrivals did occur in many countries during the guest-worker era, they were generally irregular ("tourist" migration) and concerned low-skilled workers. At the time, labour requirements were so great that the practice was tolerated and the immigrants regularised after arrival. Whether the same practice applied to more highly skilled workers is unknown; there is scarcely any consideration in the economic literature of the highly skilled migration to Europe that may have been occurring at the time. With the deterioration of economic conditions following the first oil crisis, labour migration effectively came to a halt. The exceptions allowed in many countries, when there were any, concerned precisely the possibility of admission of persons with high-level skills not available on the domestic labour market. In practice, outside of the Ireland, Switzerland and the United Kingdom, there has been little highly skilled migration into European countries, Japan or Korea.

104. In settlement countries, the tradition of the direct selection of migrants by the national administration rather than by employers developed for a number of reasons. First of all, migration policy in these countries had traditionally had a population objective that was broader than that of responding to the immediate needs of the labour market. In addition, because of the more limited communication and transportation possibilities, as well as the more domestic orientation of most enterprises at the time, it was likely the case that only the largest employers were in a position to look beyond their borders to satisfy their labour needs. It was impractical for most employers to do so, in a way that seems unimaginable today, 
when cross-border recruitment via the Internet is a simple matter and relative transportation costs have declined considerably.

105. The identification and recruitment of appropriately qualified immigrants to introduce into the domestic labour market by the national administration guaranteed a steady supply of additional labour resources over and above those available from domestic sources. The involvement of the national administration also meant that, at least in principle, possible externalities extending beyond the immediate labour needs of a small number of employers could be taken into account. The Canadian skilled selection grid over the past decade, emphasising general human capital considerations rather than the specific immediate occupational needs of employers, is one example of an attempt to do this. ${ }^{10}$

106. Despite the fact that few immigrants under the points systems had jobs upon arrival, labour force integration was rapid in the pre-1980s period and convergence to average wages of the native-born occurred within a relatively short period, often as quickly as five years. The ability of the national administration to identify immigrants who eventually did well, taking perceived national occupational or skill needs into account, seemed clearly demonstrated. Employer-initiated migration in the European traditional was reserved for temporary labour needs, which the point-systems with their processing delays were not able to address expeditiously.

107. However, there are some obvious advantages to delegating the selection process to employers. In the first place, it tends to ensure a close link between immigrant worker entries and labour market needs, provided it can be ensured that the entries are restricted to sectors and occupations where there are genuine shortages, a condition not always easy to determine. In addition, the immigrant worker is immediately employed upon arrival and thus imposes no immediate financial burden on the receiving state. ${ }^{11}$ In cases such as these, immigration helps to satisfy current, well-identified needs and in so doing, aids in moderating wage demands in the shortage areas. On the other hand, it may slow the salary adjustment process that would help generate a domestically developed supply of workers in the shortage occupations (see OECD, 2006).

108. Although the employer may satisfy the immediate labour needs of his/her enterprise, the longer term consequences of admitting the particular worker(s) in question do not usually enter into play. Moreover, when employers (or private recruitment agencies) are left in charge of the selection procedure, problems of moral hazard may arise. This is because the implicit contract between the government and firms responsible for selecting candidates does not always cover the indirect costs incurred by the receiving country (e.g. return to sending country, social costs of job loss) whenever the wrong candidate is chosen, needs are overestimated or an economic downturn occurs. Considerations such as the future employability of the worker in the event of job loss may not figure among the criteria considered important by the employer in the hiring decision. ${ }^{12}$ However, the possibility of constraining the hiring decision, by limiting it to certain categories of workers or occupations, can reduce the risk to the host country.

10 There is some evidence that it has not been entirely successful in ensuring better outcomes shortly after arrival and that this may have lasting longer-term effects (Picot and Sweetman, 2005).

11 The point-system countries have attempted to reproduce this advantage of employer-initiated migration by requiring that arrivals have sufficient funds to support themselves during a certain period while looking for work. Under the Australian skilled migration programme, new immigrants have not right to social benefits for two years after arrival.

Some economists have suggested that permits for highly skilled migrants be auctioned as a way of matching supply and demand and of capturing some of the "rents" for the receiving country. However, this idea has not made much headway among migration policy makers, 
109. One issue that arises in employer-initiated migration is its actual applicability when there is effectively no basin for the national language outside the borders of the country. In such cases it is difficult to imagine direct recruitment into a high-skilled job of workers with little to no knowledge of the hostcountry language, except in special circumstances, for example, in multinational enterprises where the language of work is English or some other commonly used international language known to the candidate. This question will be addressed further below in the section on qualifications, experience and language.

110. Supply-driven migration, although it has achieved a measure of success for countries which have implemented this form of management of migration movements, requires a considerable administrative infrastructure to process and assess applications for admission. The verification of reported qualifications, work experience and linguistic competencies imposes a certain delay, which can be as long as 18 months, and depends on an extensive network of consular offices abroad with specialised immigration officers who assess applications and carry out interviews.

111. The elaborate nature of point-system migration selection programmes does not seem to have been a handicap, judging from the relative success in labour market integration which the point-system countries have achieved in the past. However, starting in the nineteen-eighties and continuing into the nineties, these systems have started to show their limits. Around this time, the early labour market outcomes of immigrants admitted without job offers began to be much less favourable than in the past and the rapid integration and labour market success more problematical. This has coincided with often difficult economic conditions, a change in source countries towards less developed countries and large increases in the educational attainment of the domestic population. The reasons for this will be examined further below as well as the measures introduced in some countries to redress the situation.

112. In any event, the greater difficulty encountered by the point systems in identifying future successes has lead to stronger consideration being given, among others, to language ability, to the verification of qualifications in the application process, to the existence of prior job offers, to demonstrated prior success (selection of immigrant workers already in the country on a temporary status) and to preferential treatment for persons with domestic educational qualifications (in particular, possibilities for international students to stay on and work after the completion of their studies).

113. To a great extent, many of the labour market difficulties described above are finessed in employer-initiated migration, both because of the prior negotiation that occurs between the employer and the potential employee regarding wages and working conditions and because the worker is guaranteed employment from the time of arrival. There is an implicit assessment by the employer of the foreign qualifications and experience of the immigrant in the job offer, which can be considered to be freely accepted by the immigrant candidate, although it is conceivable that the employee-to-be may not be aware of the wages and working conditions which a native-born person of the same nominal qualifications and experience would obtain in the host country. Still, whatever the employer's view of the qualifications and experience of the candidate, the job offer is ample proof that in a situation of demonstrated need, they are not impediments to employment.

\section{Determining limits on numbers}

114. In addition, since the number of labour migrants to be admitted is not a function of specific employer requests, this number must be determined as a matter of government policy. In both Australia and Canada, the figures for the upcoming year are publicly announced by the Minister for Immigration each year. The numbers are based on past experience of what the "absorptive capacity" of the economy is, given current economic conditions. However, because the determination of this is at best uncertain, there are some risks involved. 
115. If too many migrants are admitted into the domestic labour market without job offers or without reference to the state of the labour market, their labour market outcomes, as well as those of the domestic work force, may suffer. To guard against this, the point-system countries have tended to make the numerical limits vary as a function of economic conditions, reducing this limit in economic downturns and increasing it in expansions. On the other hand, a numerical limit that is set too low relative to employer labour needs may result in labour market tightness, defeating one of the prime objectives of labour migration policy.

116. In a certain sense, the numerical limit under conditions of oversupply will always be too low from the point of view of potential immigrants, if the country of destination is viewed as an attractive one. This is one reason why the point-system threshold needs to be set high enough so that the number of potential candidates who exceed the threshold is not too much larger than the annual number accepted, so as to avoid the creation of large backlogs in the application process, with the resulting long delays this may impose on new applications. This is all the more the case when current specific occupational and labour needs in the domestic labour market are taken into account in assessing the suitability of candidates. With large backlogs, selected immigrants may be admitted some years after the time when the occupational need which they were intended to satisfy became manifest.

117. The issue of establishing a limit to the number of labour migrants is not entirely absent from employer-initiated migration, for the reason that the extent of labour needs must be determined here as well. Do all requests from employers represent genuine needs that cannot be filled in the domestic labour market? In practice, this is often determined empirically, by imposing "employment tests" on employers who request permits to bring in workers from abroad. They are generally required to demonstrate to the national employment service, for example through advertising the position for a certain period of time, that there are no suitable candidates resident in the country that are able or willing to take the job.

118. An alternative to employment tests is the development of a list of occupations for which there are labour shortages. This may be carried out by the public employment service, at national or regional level, and employers thereafter allowed to bring in workers with occupations on the list, generally up to a maximum. This essentially implies the existence of an overall numerical cap, which has been used in Switzerland, for example, in addition to the employment test, to avoid situations of what might be termed "excessive demand". In practice, this numerical limit was never reached until Switzerland opened up its labour market to free circulation from the European Union.

\section{Labour market tests versus shortage lists}

119. One of the principal concerns of migration policy is to ensure that immigrants do not hamper the employment prospects of native workers. Although most studies tend to show small effects of immigration on the outcomes of native-born workers (Longhi et al., 2008), this overall result is an average and it most certainly is the case that some native-born workers are hurt by the arrival of immigrants competing for the same jobs. In practice, this tends to be less of a policy concern for highly skilled workers, because their labour market outcomes are generally favourable in any case, with positive wage returns to higher education and shorter unemployment spells. ${ }^{13}$

120. In practice, most labour migration systems incorporate safeguards to protect native workers from adverse effects on labour market outcomes of discretionary labour migration. This is all the more the case since governments have limited discretionary control over the significant numbers of immigrants who arrive as family or humanitarian migrants every year, many of whom will also enter the labour market.

13 In southern Europe, where young university graduates have especially high unemployment rates, labour migration has tended to be focused on lesser skilled jobs. 
121. Supply-driven systems have no direct, overt protection for domestic workers in their selection regimes. Historically, they have incorporated an indirect protection by adjusting, as noted above, their intake according to the conditions of the labour market. ${ }^{14}$ In some cases (the Australian point-system is an example), additional points are attributed if the applicant is on a shortage occupation list, but there is no guarantee that the candidate will look for or find a job in the shortage occupation. However, if points are awarded for a job offer, the latter is generally subject to an employment test. Moreover, the job offer is no guarantee of entry if the candidate does not have sufficient points on other characteristics. ${ }^{15}$

122. Over the past decade, countries with point systems have introduced the possibility of permanent migration through regional and employer sponsorship, without the applicant having to go through the usual points assessment normally required when applying through the national skilled migration regime. The required job offers must be in occupations for which there are demonstrated local needs. In this they are similar to the employer-driven strategies common in Europe, Japan and Korea, except that the right to permanent residence continues to be granted upon entry and there is a targeted number of immigrants admitted in each participating region, with the regional targets entering into the national immigration planning.

123. The two principal means of ensuring protection of the domestic work force in demand-driven regimes are the employment test and the occupation shortage list, both of whose principal characteristics have been summarily outlined above. Until recently, the employment test was the principal method used and applied locally; it may have been subject to a certain amount of discretion by local employment officials. In some case, high unemployment conditions were deemed prima facie evidence that local alternatives existed, especially for jobs which could be filled by candidates with a broad range of formal qualifications. In testing the labour market, there may also be some flexibility with respect to the type and geographical coverage of the media used to advertise the available job and the time period it remains advertised. Moreover, the job description and requirements, as well as the working conditions, can be phrased in such a way as to limit the number of potential candidates in the host country. There is a tradeoff between the testing period and coverage and the protection afforded domestic workers. Since the employment test by itself is no assurance of high-skilled migration, host-country governments who wish to restrict movements to this category of migrants have done so by imposing minimum wage or qualification requirements which must be satisfied before a permit request will be considered.

124. The occupational shortage list has the potential of reducing the time delays and arbitrariness associated with employment tests, but at the risk of introducing other possible distortions. Occupations may be more or less broadly or narrowly defined, which can open up the labour market considerably in the former case, but be restrictive in the latter. Employers can declare a requirement for an employee with an occupation on the shortage list, when the actual need relates to a different occupation, with an adjustment negotiated with the immigrant before or after arrival in the workplace.

125. Although the shortage list can make the process more transparent and expeditious, the occupations in shortage need to be identified upstream. A comparison between the number of unfilled vacancies and the number of unemployed by occupation, carried out by national employment agencies for lesser skilled occupations, is less evident for skilled occupations, few of which may be advertised through the national employment agency. Whatever the means of establishing shortages (monitoring of vacancies or occupational wage trends, surveys of employers, consultations with employers and/or unions, etc.), the lists can be subject to validation by the social partners, which ensures a minimum of consensus.

14 The link to the conditions of the labour market was abandoned in Canada as of 1990.

15 The employer then has the option of "importing" the worker through the temporary regime. 
126. The lists need to be reviewed regularly, however, to ensure that they continue to reflect the actual labour market situation. In this respect, employment tests are always current and provide equal treatment for all occupations.

127. The shortage list should in principle distinguish between cyclical and structural shortages, that is, temporary and permanent labour needs. In practice, the difference may be difficult to make, because employers may not necessarily want to commit themselves to long-term contracts without a prior probationary period of employment or may not always themselves be certain that labour needs will be persistent. But this is also a handicap of employment tests.

128. Generally, the tendency in countries seems to be moving towards a broader use of shortage lists. They are used in France, Italy, Spain and are being developed in the United Kingdom, among others. Among the reasons for this is perhaps the fact that they reduce the scope for discretionary decisions and the administrative time delays associated with the processing and granting of work permits, which is a persistent problem in many countries.

\section{Temporary migration as a bridge to permanent migration}

129. One strategy for minimizing the labour market risks associated with immigrants arriving without prior job offers and to expand the pool of possible suitable candidates for permanent immigration is to provide for the possibility of persons present in the country on a temporary status to remain in the country on a longer-term basis.

130. In countries which have elaborate immigrant selection strategies and which accord the right of permanent residence upon entry, the temporary migration regime historically has provided a way of bringing a needed worker quickly into the host country, because processing times were much shorter and conditions for entry less stringent, even if the application process did generally include some form of employment test. The point-system countries have in the past attempted to maintain a barrier between the temporary and the permanent regimes, to avoid introducing an alternative route to permanent status that might subvert the usual overseas application process. In consequence, a person present in the country on a temporary status was normally not allowed to apply for permanent status from within the country. However, since there was no restriction on application from a neighbouring country, there were significant numbers of applications lodged in this way, with potential immigrants maintaining their temporary status in the host country during the processing period.

131. This practice also applied to international students, who in addition were subject to so-called "quarantine" provisions in many host countries if they originated from a developing country or if their studies were financed by their national governments or an aid programme. These provisions required finishing international students to return to their countries of origin for a number of years before they could be considered for immigration to the country where they had completed their studies. The restrictions had to be applied with some flexibility in practice, for example in cases where the student married a citizen of the host country. Here too, the restrictions could be subverted, by finishing students' applying for admission to a country other than that where they had completed their studies.

132. Over the past decade, a more pragmatic view has developed with respect to allowing passageways between the temporary and permanent migration regimes. In the United States and New Zealand, for example, status changes have become the principal means of recruiting permanent labour migrants (OECD, 2007), with over $70 \%$ of these involving changes from a temporary status. The reasons for the development (or the acknowledgment) of the new routes to permanent migration are fairly evident and reflect the difficulties which immigrants from non-OECD countries arriving without jobs have been having in the labour markets of OECD host countries, whether they are selected through point systems or 
admitted as family or humanitarian migrants. Candidates with formal qualifications from, and/or specific work experience in, a host country possess characteristics which would seem to automatically favour better labour market outcomes. Requiring that such candidates return to their home countries before applying for permanent immigration seemed counterproductive at best.

133. Interestingly, countries have generally followed their normal labour migration practices in considering applications for changes in status, although it would be fair to say that a hybrid system has developed in Europe and Japan, especially with respect to international students.

\section{Treatment of international students}

134. In European countries and Japan and as documented above, students who have completed their studies must have found a job related to their field of study in order to be considered for immigration, a requirement consistent with usual labour immigration practices in these countries. Generally not all fields of study are considered appropriate, with preference being given to scientific or technical fields. Finishing students are given a certain number of months in which to find a job before they must return to their country of origin. They thus enter the domestic labour market in the same way as native-born new entrants, a practice characteristic of point-system regimes.

135. Point-system countries, on the other hand, have nominally maintained their procedure of assessing candidates on the basis of their characteristics. Since points are assigned for job offers and hostcountry qualifications or work experience, in-country candidates are strongly favoured in the assessment process. International students, however, do not necessarily need to have a job offer in order to be accepted. In Australia, however, this has resulted in some anomalies, when the standard language proficiency requirement was waived for students who had completed a programme of study in Australia. Subsequent analyses showed that many such students, despite their Australian qualifications, actually had language deficiencies which made it difficult for them to obtain a job in the Australian labour market in their field of study (Birrell, Hawthorne, \& Richardson, 2006).

136. The language issue is a critical one with respect to recruitment of international students as workers, because of the proficiency generally required to move directly into a high-skilled job. However, universities are also interested in diversifying their student intake (see Table 6 for a picture of recent trends in international students). Outside of English-language countries, which are clearly in a privileged position with respect to attracting international students, strategies appear to differ across countries in this regard.

137. In some countries, English-language programmes have been introduced in order to attract students from other countries, especially when the language of the country is not or is hardly spoken outside its borders. This is the case, for example, in the Nordic countries and the Netherlands. Students in these countries can thus, in principle, live and stay in the country without necessarily having to learn very much of the national language. Although an extended presence in the country of study may enhance the likelihood of an eventual permanent stay, study in English unquestionably prepares students for work in English-language workplaces which are likely not common in these host countries outside of multinational enterprises, even if substantial proportions of residents and workers of the country are able to understand and speak English. The ability of an international student to function at a high level in the language of the country of study under these conditions is far from assured. Whether the expanded use of English in work places and in commercial transactions will be sufficient to make direct recruitment of international students into jobs a more common phenomenon is uncertain.

138. Other countries, such as Belgium, France, Switzerland and Spain have national languages that are spoken broadly outside of their borders and, as such, are in a privileged position to attract many international students to programmes offered in the host-country language. 
139. Other countries have managed to attract significant numbers of students for programmes in the host- country language, although there may also be some courses and programmes offered in English. These include Germany, Italy, Japan and Korea. Often such students have to do a preparatory year to acquire the needed language proficiency before they are able to follow a programme entirely in the hostcountry language. This does not seem to be an insurmountable obstacle, given the numbers of international students which Germany and Japan are able to attract, 205000 and 118 000, respectively. In Germany, tuition fees are quite low for international students, which may be an additional incentive if affordability is a significant issue.

140. Although international students are a potential source of highly skilled labour migrants for OECD countries, there is no systematic data as yet on stay rates. Results from a number of countries suggest that at best $15-20 \%$ of graduates may be staying on (OECD, 2007), with differences by country of origin. Because of the "quarantine" provisions for students from developing countries in the past, the numbers were relatively limited and often restricted to situations in which the student married a citizen of the host country. As a result of current policies, the possibilities are now more significant, but since allowed occupations generally have to be in a technical or scientific field, the pool of potential candidates is substantially reduced. On average, some 10 to $15 \%$ of international students are studying in each of engineering, manufacturing and construction; health and welfare; and the sciences. For this restricted pool of candidates, the effective stay rates may actually be higher. Still, with the expansion of international study, the absolute number of students returning to their countries with an education obtained in an OECD country is likely to have increased over the past decade.

\section{Qualifications, experience and language: key determinants for labour market outcomes}

\section{The diagnosis}

141. Table 9 shows the labour market outcomes of highly-qualified migrants in a number of OECD countries, including in particular the skill level of the job held for those employed. Only in a few countries do more than $55 \%$ of highly-qualified migrants also work in high-skilled jobs ${ }^{16}$, whereas this is on average the case for about $70 \%$ of highly-qualified native-born. Often, they are not so much more "overqualified" than native-born workers, in the sense that proportionally more of them work in a medium- or low-skilled occupation, as they are unutilised, that is, they are either unemployed or not in the labour force. ${ }^{17}$ The results in this table apply not only to labour migrants but to all migrants, including family and humanitarian migrants. They reflect to a certain extent labour force outcomes for persons many of whom arrived without jobs and thus entered the labour market without a prior recognition of their qualifications and experience.

16 A high-skilled job is defined as a managerial job or one classified as "professional" or "associate professional" in the International Standard Classification of Occupations (ISCO, 1988).

17 The exceptions are Denmark and Sweden, where the differences in the extent of overqualification between the native-born and the foreign-born are especially large and where the differences are accounted for about equally by a greater presence in jobs normally requiring lower education levels and a higher prevalence of unemployment and inactivity. 
DELSA/ELSA/WD/SEM(2009)5

Table 9. Labour market outcomes of tertiary-educated native- and foreign-born persons, 15-64, 2005-2006 averages Percentage

In high-skilled job In medium-skilled job In low-skilled job Unemployed Not in labour force

\begin{tabular}{|c|c|c|c|c|c|c|}
\hline \multirow[t]{2}{*}{ Switzerland } & Foreign-born & 67 & 14 & 1 & 5 & 13 \\
\hline & Native-born & 74 & 18 & 1 & 2 & 6 \\
\hline \multirow[t]{2}{*}{ Netherlands } & Foreign-born & 61 & 13 & 2 & 5 & 19 \\
\hline & Native-born & 75 & 11 & 1 & 2 & 11 \\
\hline \multirow[t]{2}{*}{ United States } & Foreign-born & 53 & 21 & 5 & 2 & 19 \\
\hline & Native-born & 60 & 21 & 3 & 2 & 14 \\
\hline \multirow[t]{2}{*}{ Austria } & Foreign-born & 53 & 18 & 4 & 5 & 20 \\
\hline & Native-born & 68 & 17 & 1 & 2 & 11 \\
\hline \multirow[t]{2}{*}{ Sweden } & Foreign-born & 53 & 18 & 3 & 9 & 17 \\
\hline & Native-born & 78 & 10 & 1 & 3 & 9 \\
\hline \multirow[t]{2}{*}{ Belgium } & Foreign-born & 53 & 17 & 3 & 8 & 19 \\
\hline & Native-born & 66 & 18 & 1 & 3 & 13 \\
\hline \multirow[t]{2}{*}{ Denmark } & Foreign-born & 53 & 14 & 6 & 6 & 0 \\
\hline & Native-born & 76 & 10 & 1 & 3 & 10 \\
\hline \multirow[t]{2}{*}{ Germany* } & Foreign-born & 51 & 16 & 4 & 10 & 19 \\
\hline & Native-born & 68 & 17 & 1 & 4 & 10 \\
\hline \multirow[t]{2}{*}{ France } & Foreign-born & 51 & 13 & 3 & 10 & 23 \\
\hline & Native-born & 62 & 14 & 1 & 5 & 17 \\
\hline \multirow[t]{2}{*}{ Average } & Foreign-born & 55 & 16 & 4 & 7 & 9 \\
\hline & Native-born & 70 & 15 & 1 & 3 & \\
\hline
\end{tabular}

Notes:* 2005 only. For example, in Switzerland among all tertiary-educated persons $67 \%$ are employed in a high-skilled job, $14 \%$ are employed in a medium-skilled job, $1 \%$ are employed in a low-skilled job, $5 \%$ are unemployed and $13 \%$ are inactive. As a consequence the unemployment category cannot be interpreted as an unemployment rate.

Sources: European community labour force survey for European countries, Current Population Survey for the United States.

142. There are undoubtedly a number of reasons for these less favourable labour market outcomes, but the evidence is accumulating that one significant reason for this is the fact that employers attribute less value to qualifications and experience obtained abroad, and in particular from a non-OECD country, than to those from more developed countries. The differences in employment rates between the native-born and the foreign-born in Table 9 are already a suggestive indication of this. We will not review here the evidence for this, which is covered elsewhere (OECD, 2007b), but rather consider the implications this has for migration policy involving the highly skilled.

143. The settlement countries, to a greater or lesser extent, have concluded that given current labour market outcomes of some highly skilled immigrants of the kind shown in Table 9, the assumption of the nominal equivalence of foreign qualifications and experience to domestic standards in the assessment of candidates has turned out to be a flawed selection strategy. The means implemented to address this problem have essentially involved, in one way or another, adopting measures to increase the prior information available to the employer regarding the skill level of immigrant applicants for employment. Although European countries and Japan do not generally admit immigrant workers without prior offers of employment, the same sorts of problems are encountered with family and humanitarian migrants and some of the corrective policy actions are applicable.

144. The most obvious means of responding to employer reticence about immigrant candidates for employment is to transfer some or all of the responsibility for immigration selection to the employer, in the European tradition. It is then the employer who addresses qualification and experience issues as part of the hiring negotiations with the person to be recruited. As noted earlier, the settlement countries now offer points for job offers and have introduced employer-initiated permanent migration channels that now bypass the point-system evaluations.

145. A second is to implement measures for the assessment and recognition of foreign qualifications. This is especially critical in regulated professions, which require licensing or certification and which may cover a significant part of high-skilled employment. Actual data on the extent of recognition are difficult to 
obtain, but anecdotal information suggests that only a minority of foreign qualifications that are assessed may be recognised as fully equivalent, but that for many candidates, full equivalence can be obtained by means of bridging courses. In Australia, persons interested in migrating as skilled workers must have their qualifications assessed before lodging an application, to ensure that they are sufficiently qualified for their occupation in the Australian labour market. In other countries, labour migrants are advised to have their qualifications assessed before arrival, but it is not a pre-requisite for acceptance or entry.

146. A third measure is to favour candidates with qualifications and/or experience obtained in the host country, in another OECD country or in recognised institutions outside of the OECD. This is the measure favoured by more and more countries. In Australia, for example, in 2003-2004, about 55\% of the principal applicants who immigrated in the skilled independent visa group had Australian qualifications.

147. The recognition of foreign qualifications and experience, however, begs the question of whether the immigrants actually have the linguistic skills necessary to exercise a particular occupation in the host country.

\section{Proficiency in the host country language}

148. Proficiency in the host-country language is usually a prerequisite for making full use of the migrant's skills, qualifications and experience in the host country. This is especially the case for high-skill jobs. Indeed, there is some evidence that language mastery is becoming more important in skilled jobs due to work practices and new technologies which enhance the importance of communicative skills and, thereby, language mastery (Rosholm, Røed and Schøne, 2006). The issue of language mastery has implications for immigrant selection and post-arrival integration programmes.

149. In situations where the national language is scarcely spoken outside the borders of a potential host country, the pool of potential foreign applicants able to be recruited directly into a high-skilled job may be limited, if not entirely non-existent. ${ }^{18}$ There are possibilities for recruitment into workplaces where, for example, English or some other broadly used language is spoken, but this may be limited to multinationals. In any event, intra-corporate migration of this kind is already relatively free of control for high-level positions, ${ }^{19}$ although delays and administrative inefficiencies may still be a problem in some countries. There may be a certain amount of self-exclusion by employers with regard to overseas recruitment, because they are aware of the limited pool of speakers of the national language.

150. Even if English is spoken and understood by nearly everyone in the workplace, it may not be the language of work, especially in small and medium-sized enterprises. In practice, this means that the immigrant will need to make a significant investment in language learning in order to reach an appropriate level of language expertise in the work place, with the ability to write, speak and understand at a relatively high level. This is a long-term investment which does not seem entirely compatible with temporary migration.

18 Certain countries (Japan, Korea, Finland, and Hungary) are trying to lure back children of former emigrants or ethnic migrants, reasoning that they will have at least an elementary command of the language which will greatly facilitate further learning and integration into the work place.

19 Under the GATS (General Agreement on Trade in Services), most country commitments on movement are restricted to senior managers and very highly qualified professionals of multinational enterprises. Actual national practices may be more liberal than this, however, especially with respect to major, well-known multinationals. Where this is the case, one would expect a priori that movements of highly qualified labour migrants to take up jobs with a host-country firm would also be less subject to regulatory control, but this form of movement is often still subject to an employment test. 
151. Regardless of how an immigrant is selected, the funding of language training is an issue. In Australia, however, it does not arise for skill-selected migrants, because a fairly high level of language proficiency is required to even have one's candidacy considered. The Canadian migration programme provides points for language proficiency in the host-country languages(s), but there is no minimum level of competence. It also offers free language training to all adult permanent residents, whether or not they were selected in the skill stream or are looking to work. Since there are externalities related to language proficiency, such as a better social integration, more participation in civic life, etc. there is an argument for government involvement in the funding of it for new arrivals, whether or not they arrive directly into a job or wait to acquire the required proficiency level before searching for work.

152. The lack of language proficiency may not always be a handicap, however, if full proficiency is not needed for the jobs held by immigrants. A recent study by Chiswick and Miller (2007b) suggests that in the United States the labour market tends to match immigrant worker's English skills and the language proficiency requirements of occupations.

153. Still, there is no escaping the clear advantage which countries speaking a language widely used outside their borders have in attracting highly skilled migrants directly into jobs. Countries for which this is not the case will need to make significant efforts in convincing potential candidates to make the investment in the national language needed to ensure high-level performance in the workplace. English may serve as a bridging language in the period after arrival, but there is no avoiding the mastery of the national language which a long-term residence in the host country requires.

\section{Summary and conclusions}

154. This document provides a preliminary overview of highly skilled migration in OECD countries in recent years, of policies which governments have introduced with regard to this kind of migration and of the issues underlying a number of the policy options.

155. The most important contrast with regard to highly skilled migration is that between supply-driven migration programmes (administered through point systems), which tend to have target labour migration levels, and demand-driven programmes, where the employer is the linchpin, but where the needs of the labour market determine the scale of entries. Two developments have driven a convergence between the two types of programmes in recent years.

156. The first is the fact that labour market outcomes for highly educated immigrants arriving without a prior job offer, whether they are labour, family or humanitarian migrants, are not as favourable as they used to be. In particular, significant proportions of them are not holding jobs commensurate with their qualifications. This has resulted in countries which have favoured this kind of migration in the past moving towards a more demand-driven system. For example, they now tend to favour candidates with job offers or already working in the country on a temporary status or with domestic educational qualifications, as well as by a strengthening of language requirements.

157. The second is that direct employer recruitment has not always attracted in sufficient numbers the kind of very highly qualified immigrant which host countries were looking for, with the potential to contribute to research, innovation and economic growth. Some of these may have been educated in hostcountry institutions but had little opportunity to stay on after completion of their studies. Others were resident abroad, may have been attracted by migration, but had no specific job offers. Point-system regimes have shown an ability to reach this kind of potential migrant. In both cases, the policy adopted by the employer-driven regimes is to provide for the possibility of searching for work in the host-country labour markets by selected immigrants or possible candidates for immigration. This is the strategy for 
matching supply and demand used by the point-system countries, with the difference, however, that for finishing students an unsuccessful search effort has generally implied a return to the home country.

158. Because many highly qualified immigrants continue to arrive without job offers in many countries, the issue of credential assessment, recognition and upgrading remains pertinent, especially in regulated occupations. Over-qualification, however, may not always be a matter of unrecognised or nonequivalent credentials, but of inadequate language proficiency.

159. The issue of language poses particular problems for countries for which there are limited speakers of the national language outside the national borders. It seems no accident that countries which have seen recent increases in the share of highly qualified migrants all have national languages with significant numbers of speakers outside their national borders. For other countries, direct recruitment of highly qualified immigrants into jobs is less than obvious, except for enterprises where English is the language of work. Because of the significant language investment required by highly qualified immigrants interested in moving to such countries, immigration may need to be viewed more in a settlement perspective and recruitment and integration policies adapted accordingly.

160. An active recruitment policy, however, means more than just allowing for the possibility of granting permits to employers or to aspirant immigrants based on credentials. Almost all OECD countries have opened channels and granted exemptions from burdensome administrative procedures for the highest skilled with a job offer. Simply lowering the barrier cannot be defined as a recruitment policy. While highskilled migrants may be attracted to countries with widely spoken languages and high wages regardless of the obstacles, a lower wage country with its own unique language cannot become internationally competitive only by lowering the administrative barriers. These countries will have to implement more active recruitment policy, including reaching out - through international job fairs, multilingual job postings, special assistance to high-skilled immigrants, attractive terms for international students in key sectors - in order to achieve their human resource objectives.

161. The effects of demographic change are only beginning to be felt in most countries. By 2010, however, more than half of OECD countries will show incoming labour force cohorts which are smaller than outgoing ones. In the short-term, a mobilisation of the unused domestic labour supply may help to ease labour market pressures, but the possibilities in the case of highly skilled persons are more limited, because of already high participation rates. Current levels of family and humanitarian migration will no doubt make up for some of the shortfall, but less restrictive policies with respect to discretionary highly skilled migration need to be blue-printed, if not necessarily implemented as yet. The objective over the medium-term is to ensure the right scale and nature of movements to satisfy labour market needs. It would be premature to claim that all of the required policies are already in place. 
ANNEX: POLICIES FOR HIGH-SKILLED IMMIGRANTS IN THE OECD

\begin{tabular}{|c|c|c|c|}
\hline & AUSTRALIA & AUSTRIA & BELGIUM \\
\hline $\begin{array}{l}\text { Permanent migration } \\
\text { programmes relevant for } \\
\text { highly skilled workers } \\
\text { PTS: Point system }\end{array}$ & $\begin{array}{l}\text { - General Skilled Migration Programme (GSM) - PTS } \\
\text { - Employer Nomination Scheme\} (EN) - PTS } \\
\text { - Regional Sponsored Migration Scheme (RSM) - PTS }\end{array}$ & $\begin{array}{l}\text { - Permanent residence permit and unrestricted work } \\
\text { permit (generally after } 5 \text { years of residence and fulfilment of } \\
\text { the integration agreement) } \\
\text { EU-8 nationals after } 1 \text { year and third country nationals with a } \\
\text { key worker permit after } 18 \text { months can get an unlimited } \\
\text { residence permit. }\end{array}$ & $\begin{array}{l}\text { - A Permit (generally after } 4 \text { years of continuous residence } \\
\text { with a B permit over the last } 10 \text { years) }\end{array}$ \\
\hline $\begin{array}{l}\text { Main temporary } \\
\text { migration programmes } \\
\text { relevant for highly } \\
\text { skilled workers } \\
\text { \#Y : maximum duration } \\
\text { R : renewable } \\
\text { LMT : labour market test }\end{array}$ & - Temporary business long stay (457) $4 Y R$ & $\begin{array}{l}\text { - Key workers permits } \\
\text { - Restricted work permit } 1 \text { YR LMT } \\
\text { - Work permit } 2 \text { YR LMT ( } 52 \text { weeks in employment over the } \\
\text { last } 14 \text { months) }\end{array}$ & $\begin{array}{l}\text { - B Permit } 1 Y R \text { LMT and limited to bilateral agreements } \\
\text { (wage } \geq € 33 \mathrm{k} \text { no LMT and no condition on nationality. UE8 } \\
\text { nationals with a job offer can get a Permit B without LMT) } \\
\text { - "Professional Card" for Independent practice delivered } \\
\text { by SPF Économie, } 5 \text { YR }\end{array}$ \\
\hline Quota & Yes. Cap of 108500 for 2007-2008. Queue spillover. & Yes & No \\
\hline $\begin{array}{l}\text { Characteristics of the } \\
\text { Labour Market Test }\end{array}$ & $\begin{array}{l}\text { Shortage list occupations only. No LMT, although salary is } \\
\text { verified. }\end{array}$ & $\begin{array}{l}\text { No registered unemployed person is available and the } \\
\text { employer respects applicable wages and labour law. }\end{array}$ & $\begin{array}{l}\text { B permit issued if a worker cannot be found or trained } \\
\text { "within a reasonable delay". Approval is within } 30 \text { days of } \\
\text { application to the responsible labour office. }\end{array}$ \\
\hline Shortage occupation list & $\begin{array}{l}\text { SOL, Employer Nomination (ENSOL), MODL (bonus points } \\
\text { for PR) }\end{array}$ & No & Yes \\
\hline $\begin{array}{l}\text { Foreign students can } \\
\text { change status after the } \\
\text { completion of their } \\
\text { studies }\end{array}$ & $\begin{array}{l}\text { Skill Independent (880), Australian Sponsored (881) \& } \\
\text { Designated Area Overseas Student (882) }\end{array}$ & Possible, but no specific programme. & Possible, but no specific programme \\
\hline
\end{tabular}


DELSA/ELSA/WD/SEM(2009)5

\begin{tabular}{|c|c|c|c|}
\hline & CANADA & CZECH REPUBLIC & DENMARK \\
\hline $\begin{array}{l}\text { Permanent migration } \\
\text { programmes relevant for } \\
\text { highly skilled workers } \\
\text { PTS: Point system }\end{array}$ & $\begin{array}{l}\text { - Skilled Worker Class (R 75) - PTS } \\
\text { - Provincial Nominee Class (R 87) }\end{array}$ & $\begin{array}{l}\text { - Permanent Residence (after } 5 \text { years of continuous } \\
\text { residence with a Long term Residence Permit; this is } \\
\text { shortened to } 2.5 \text { YR for qualified workers and } 1.5 \text { YR for } \\
\text { highly qualified - tertiary educated - workers). }\end{array}$ & - Permanent Residence permit (after 7 years ) \\
\hline $\begin{array}{l}\text { Main temporary } \\
\text { migration programmes } \\
\text { relevant for highly } \\
\text { skilled workers } \\
\text { \#Y : maximum duration } \\
R: \text { renewable } \\
\text { LMT : labour market test }\end{array}$ & $\begin{array}{l}\text { - Temporary Foreign Worker (R200) limited to the duration } \\
\text { of employment, LMT except if included in Regional Lists of } \\
\text { Occupations under Pressure } \\
\text {-TN visa } 1 \text { YR (NAFTA) }\end{array}$ & $\begin{array}{l}\text { - Long-term Residence Permit for the purpose of } \\
\text { employment }>1 Y R \text { LMT } \\
\text { - Work Permit 1YR LMT } \\
\text { - Project of Active Selection of Qualified Foreign Labour } \\
\text { for young qualified foreigners (quicker access to a } \\
\text { permanent resident status). }\end{array}$ & $\begin{array}{l}\text { - Work Permit 1YR LMT } \\
\text { - Job Card Scheme } 3 Y R \text { for occupations in the "positive } \\
\text { list" or a job offer } \geq \text { DKK } 463 \mathrm{k} \\
\text { - Green Card: } 6 \text {-month job-search permit issued on the } \\
\text { basis of points for education, language, shortage list, } \\
\text { experience, prior wages, experience, age. Must be } \\
\text { converted to Job Card permit before expiry. }\end{array}$ \\
\hline Quota & $\begin{array}{l}\text { No (target of } 129000 \text { to } 142000 \text { in } 2007 \text { for Skilled Worker, } \\
\text { Quebec Skilled Worker and Provincial Nominee) }\end{array}$ & No & No \\
\hline $\begin{array}{l}\text { Characteristics of the } \\
\text { Labour Market Test }\end{array}$ & $\begin{array}{l}\text { Temporary Foreign Worker: Labour market opinion, with } \\
\text { demonstration of attempts to fill position (advertisements, } \\
\text { etc. and public employment service), verification of } \\
\text { prevailing wage and conditions. The LMO also considers } \\
\text { whether "employment of the foreign worker will directly } \\
\text { create new jobs or retain jobs for Canadians". Trade union } \\
\text { approval will accelerate the process. No LMO necessary for } \\
\text { "Occupations under pressure". } \\
\text { Permanent Migration: Arranged Employment Opinion for } \\
\text { Skilled Workers provides additional points under the point } \\
\text { system. }\end{array}$ & $\begin{array}{l}\text { Employer must be authorized by Public Employment } \\
\text { Service, and job is checked against registered unemployed } \\
\text { for } 30 \text { days. }\end{array}$ & $\begin{array}{l}\text { Danish Immigration Service consults the relevant trade } \\
\text { union, except for shortage list occupations. }\end{array}$ \\
\hline Shortage occupation list & $\begin{array}{l}\text { Regional Lists of Occupations under Pressure (only for } \\
\text { Temporary Foreign Workers) }\end{array}$ & No & $\begin{array}{l}\text { Positive list of occupations. Generally masters-level, in } \\
\text { health, science, management, architecture/engineering, law, } \\
\text { etc. }\end{array}$ \\
\hline $\begin{array}{l}\text { Foreign students can } \\
\text { change status after the } \\
\text { completion of their } \\
\text { studies }\end{array}$ & $\begin{array}{l}\text { Possible. The Post-Graduation Work Permit Program } \\
\text { grants up to } 3 Y R \text { permit to work. This is important to acquire } \\
\text { "Canadian Experience" for permanent residence. }\end{array}$ & $\begin{array}{l}\text { Possible, accelerated access to Permanent Residence (2.5 } \\
\text { or } 1.5 \text { YR depending on degree) }\end{array}$ & $\begin{array}{l}\text { Possible. Automatic 6-month extension after graduation to } \\
\text { seek work under Green Card terms. Study counts for } \\
\text { permanent residence requirement. }\end{array}$ \\
\hline
\end{tabular}




\begin{tabular}{|c|c|c|c|}
\hline & FINLAND & FRANCE & GERMANY \\
\hline $\begin{array}{l}\text { Permanent migration } \\
\text { programmes relevant for } \\
\text { highly skilled workers } \\
\text { PTS: Point system }\end{array}$ & - Permanent permit $\mathbf{P}$ (after 4 years with a A-permit) & $\begin{array}{l}\text { - Residence permit (after } 3 \text { years for people with a } \\
\text { permanent worker permit) }\end{array}$ & $\begin{array}{l}\text { - Settlement permit (generally after } 5 \text { years of residence or } \\
\text { immediately for highly qualified - researchers, university } \\
\text { professors, those with a job offer over EUR } 65.6 \mathrm{~K} \\
\text { annually) }\end{array}$ \\
\hline $\begin{array}{l}\text { Main temporary } \\
\text { migration programmes } \\
\text { relevant for highly } \\
\text { skilled workers } \\
\text { \#Y : maximum duration } \\
\text { R : renewable } \\
\text { LMT : labour market test }\end{array}$ & $\begin{array}{l}\text { - A-Permit 3YR LMT } \\
\text { - B-Permit 1YR LMT }\end{array}$ & $\begin{array}{l}\text { - Permanent worker permit 1YR LMT : a job contract for } \\
\text { unlimited duration is needed (Carte de Séjour Temporaire } \\
\text { salarié) } \\
\text { - Temporary work permit <1YR LMT (Autorisation } \\
\text { Provisoire de Travail) } \\
\text { - Card "Compétences et Talents" 3YR }\end{array}$ & $\begin{array}{l}\text {-Temporarily restricted residence permit for the } \\
\text { purpose of employment (1YR LMT) for people with a post } \\
\text { secondary qualifying education. It is subject to a local LMT } \\
\text { and to Federal Employment Agency agreement. } \\
\text { "Tolerated" foreigners with qualifications and experience in } \\
\text { qualified jobs can obtain a residence permit. }\end{array}$ \\
\hline Quota & No & No & No \\
\hline $\begin{array}{l}\text { Characteristics of the } \\
\text { Labour Market Test }\end{array}$ & $\begin{array}{l}\text { Employers or job applicants must apply for authorisation } \\
\text { from the Public Employment Service, which lists the job for } \\
2-4 \text { weeks, except for occupations on the regional shortage } \\
\text { list. Local labour market authorities also check the skill level } \\
\text { and that the job offer satisfies collective agreements. }\end{array}$ & $\begin{array}{l}\text { Employer must publish position with the Public Employment } \\
\text { Service, and submit application to the Departmental Labour, } \\
\text { Employment and Vocational Training service for a } \\
\text { discretionary review of professional qualifications, contract } \\
\text { wage and conditions, the technological and commercial } \\
\text { added value of the foreign worker, and the employer's } \\
\text { guarantee of available housing. }\end{array}$ & $\begin{array}{l}\text { Local labour market test, certain categories and shortage } \\
\text { areas provide exemption from vacancy listing. Graduates } \\
\text { of German secondary schools abroad are exempt from } \\
\text { LMT if they hold tertiary degrees. }\end{array}$ \\
\hline Shortage occupation list & Regional list for each of 15 regions. & $\begin{array}{l}\text { Since } 2006 \text { there is a shortage occupation list for nationals } \\
\text { of new EU member states (LMT exemption); since } 2007 \text { a } \\
\text { separate, shorter, list for } 3^{\text {rd }} \text { country nationals (access only } \\
\text { for these occupations). }\end{array}$ & $\begin{array}{l}\text { Possible; used only for engineers from new EU member } \\
\text { states, although all tertiary educated EU citizens will have } \\
\text { free access from } 1 / 1 / 2009 \text {. The "Qualified Labour Shortage } \\
\text { Monitoring" will also be expanded. }\end{array}$ \\
\hline $\begin{array}{l}\text { Foreign students can } \\
\text { change status after the } \\
\text { completion of their } \\
\text { studies }\end{array}$ & $\begin{array}{l}\text { Foreign students who earn a degree in Finland can apply } \\
\text { for a work permit for a maximum of six months. }\end{array}$ & $\begin{array}{l}\text { Student with a French master degree, with the perspective } \\
\text { to return in their origin country, can ask for } 6 \text { months permit } \\
\text { to seek work in their field, and receive a permit exempt from } \\
\text { the LMT. Other foreign students can change status under } \\
\text { general rules. }\end{array}$ & $\begin{array}{l}\text { Students are entitled to remain in Germany for up to one } \\
\text { year after successfully completing their studies for the } \\
\text { purpose of seeking employment. They are exempt from the } \\
\text { LMT. }\end{array}$ \\
\hline
\end{tabular}


DELSA/ELSA/WD/SEM(2009)5

\begin{tabular}{|c|c|c|c|}
\hline & GREECE & IRELAND & ITALY \\
\hline $\begin{array}{l}\text { Permanent migration } \\
\text { programmes relevant for } \\
\text { highly skilled workers } \\
\text { PTS: Point system }\end{array}$ & $\begin{array}{l}\text { - Residence permit -employment (1YR but may be } \\
\text { indefinite after } 10 \text { years) }\end{array}$ & $\begin{array}{l}\text { - Long term residency permit (validity } 5 \text { years after } 5 \text { years } \\
\text { of residence and unlimited duration after } 10 \text { years) }\end{array}$ & - Residence permit (possible after 5 years of legal stay) \\
\hline $\begin{array}{l}\text { Main temporary } \\
\text { migration programmes } \\
\text { relevant for highly } \\
\text { skilled workers } \\
\text { \#Y : maximum duration } \\
\text { R : renewable } \\
\text { LMT : labour market test }\end{array}$ & - A-permit 1YR LMT & $\begin{array}{l}\text { - Green card permit } 2 Y R \quad(€ 30 \mathrm{k}<\text { salary }<€ 60 \mathrm{k} \text { and } \\
\text { shortage occupation list or all occupation with salary }>€ 60 \mathrm{k}) \\
\text { - Work permit } 1 \mathrm{YR} \text { LMT (salary }<€ 30 \mathrm{k} \text {, occupation should } \\
\text { not be included in the ineligible occupation list) }\end{array}$ & $\begin{array}{l}\text { - Work permit 1YR LMT (fix term contract) } \\
\text { - Work permit 2YR LMT (open end contract) }\end{array}$ \\
\hline Quota & No & No & $\begin{array}{l}\text { Yes (170 } 000 \text { in 2007) with some exceptions (nurses, } \\
\text { university professors, researchers, artists, etc.) }\end{array}$ \\
\hline $\begin{array}{l}\text { Characteristics of the } \\
\text { Labour Market Test }\end{array}$ & $\begin{array}{l}\text { Submission to the public employment service (OAED) for } \\
\text { approval. }\end{array}$ & $\begin{array}{l}\text { Advertisements in the national and/or local press, showing } \\
\text { that the positions could not be filled from within the EEA }\end{array}$ & $\begin{array}{l}\text { Listing with public employment service. Automatic approval } \\
\text { even without response after } 21 \text {-day listing. }\end{array}$ \\
\hline $\begin{array}{l}\text { Foreign students can } \\
\text { change status after the } \\
\text { completion of their } \\
\text { studies }\end{array}$ & Possible, but no specific programme & $\begin{array}{l}\text { Students who completed a primary, master or doctorate } \\
\text { degree may be permitted to remain in Ireland for } 6 \text { months } \\
\text { to seek employment. }\end{array}$ & $\begin{array}{l}\text { Yes, annual quota sets a maximum number of conversions } \\
\text { of study permit to work permits ( } 3000 \text { in } 2007) \text {. }\end{array}$ \\
\hline
\end{tabular}


DELSA/ELSA/WD/SEM(2009)5

\begin{tabular}{|c|c|c|c|c|}
\hline & JAPAN & KOREA & LUXEMBOURG & NETHERLANDS \\
\hline $\begin{array}{l}\text { Permanent migration } \\
\text { programmes relevant for } \\
\text { highly skilled workers } \\
\text { PTS: Point system }\end{array}$ & $\begin{array}{l}\text { - Permanent resident (after } 10 \text { years of } \\
\text { residence and still need a re-entry permit } \\
\text { before leaving Japan) }\end{array}$ & $\begin{array}{l}\text { F-5: Approval by Ministry of Justice for } \\
\text { employed people with approved salary level } \\
\text { and: doctorate level in specific field; bachelor } \\
\text { level/technology and } 3 Y \text {; exceptional ability; } \\
\text { E-5 or E-7 permit after } 5 \text { Y. }\end{array}$ & - Permit type $\mathbf{C}$ (after 5 years of residence) & $\begin{array}{l}\text { - Permanent residence permit (after } 5 \\
\text { years of residence) }\end{array}$ \\
\hline $\begin{array}{l}\text { Main temporary } \\
\text { migration programmes } \\
\text { relevant for highly } \\
\text { skilled workers } \\
\text { \#Y: maximum duration } \\
\text { R : renewable } \\
\text { LMT : labour market test }\end{array}$ & $\begin{array}{l}\text { - Work visa } \\
1 \text { or } 3 \text { Y R. Requires college degree or } 10 \\
\text { years of professional experience. }\end{array}$ & $\begin{array}{l}\text { - E-5 1YR LMT (Professional Employment - } \\
\text { law, accounting, or certain medical area) } \\
\text { - E-7 1YR LMT (Specially Designated Activities } \\
\text { - information technology) }\end{array}$ & $\begin{array}{l}\text { - Permit type A } 1 Y R \text { LMT (cannot change } \\
\text { employer or occupation) } \\
\text { - Permit type B } 4 Y R \text { LMT (cannot change } \\
\text { occupation) }\end{array}$ & $\begin{array}{l}\text { - Labour migrant work permit } 3 Y \text { LMT } \\
\text { non renewable. In general people are } \\
\text { required to take a civil immigration test in } \\
\text { their home country (Applicants must be } \\
\text { between the ages of } 18-45 \text { ) } \\
\text { - Highly skilled migrant } 5 Y \text { (wage } \geq \\
€ 33.3 \mathrm{k} \text { for people under } 30 \text { or wage } \geq \\
€ 45.5 \mathrm{k} \text {. No LMT and spouse can work) }\end{array}$ \\
\hline Quota & $\begin{array}{l}\text { No, although some bilateral agreements - not } \\
\text { yet ratified - have addressed nurses (e.g., } \\
\text { Philippines, Indonesia) }\end{array}$ & No & No & No \\
\hline $\begin{array}{l}\text { Characteristics of the } \\
\text { Labour Market Test }\end{array}$ & None. & $\begin{array}{l}\text { Letter of recommendation of employment from } \\
\text { the head of state administration or document } \\
\text { proving the necessity of employment. }\end{array}$ & $\begin{array}{l}\text { Job must be submitted to the public } \\
\text { employment service (ADEM). If no } \\
\text { candidates are registered, the application } \\
\text { may be approved. }\end{array}$ & $\begin{array}{l}\text { Centre for Work and Income must } \\
\text { approve employer request, which must } \\
\text { meet minimum wage to support entire } \\
\text { accompanying family. }\end{array}$ \\
\hline Shortage occupation list & No & No & No & $\begin{array}{l}\text { No, but in some cases the labour market } \\
\text { test can be lifted for specific occupations } \\
\text { or sectors. }\end{array}$ \\
\hline $\begin{array}{l}\text { Foreign students can } \\
\text { change status after the } \\
\text { completion of their } \\
\text { studies }\end{array}$ & $\begin{array}{l}\text { Yes, graduating students are granted a 6- } \\
\text { month Temporary Visitor permit to seek work }\end{array}$ & Possible, but no specific programme & Possible, but no specific programme & $\begin{array}{l}\text { Yes, international students after } \\
\text { graduating can stay for up to } 3 \text { months to } \\
\text { seek a job. }\end{array}$ \\
\hline
\end{tabular}




\section{DELSA/ELSA/WD/SEM(2009)5}

\begin{tabular}{|c|c|c|c|}
\hline & NEW ZEALAND & NORWAY & POLAND \\
\hline $\begin{array}{l}\text { Permanent migration } \\
\text { programmes relevant for } \\
\text { highly skilled workers } \\
\text { PTS: Point system }\end{array}$ & - Skilled Migrant Category (SMC) - PTS & $\begin{array}{l}\text { - Permanent residence permit (after } 3 \text { years with } \\
\text { temporary permit) }\end{array}$ & - Settlement permit (after 5 years of residence) \\
\hline $\begin{array}{l}\text { Main temporary } \\
\text { migration programmes } \\
\text { relevant for highly } \\
\text { skilled workers } \\
\text { \#Y: maximum duration } \\
\text { R : renewable } \\
\text { LMT : labour market test }\end{array}$ & $\begin{array}{l}\text { Work to Residence policy : } \\
\text { - Accredited employer (talent programme) } \\
\text { - Long Term Skill Shortage List } \\
\text { Work permits : LMT } \\
\text { Working holidays } 1 Y \text { (work period } \leq 6 \text { months) }\end{array}$ & $\begin{array}{l}\text { - Skilled worker / specialist (SWS) 1YR } \\
\text { - Job seeker visa (generally } 3 \text { months) }\end{array}$ & - Work Permit 1YR LMT \\
\hline Quota & No & $\begin{array}{l}\text { Yes for skilled worker specialists, ( } 5000 \text { in } 2007 \text { ) but if the } \\
\text { quota is full, it is still possible to grant a permit following LMT }\end{array}$ & No \\
\hline $\begin{array}{l}\text { Characteristics of the } \\
\text { Labour Market Test }\end{array}$ & $\begin{array}{l}\text { For work permits: The employer must make "a genuine } \\
\text { attempt" to recruit suitable resident workers. The application } \\
\text { is rejected if suitable workers are available in New Zealand, } \\
\text { but not "prepared to do the work on the terms and } \\
\text { conditions proposed by the employer", or if the employer } \\
\text { could "readily train" residents to do the work. Exemption } \\
\text { from LMT is the occupation is listed in the ISSL. }\end{array}$ & $\begin{array}{l}\text { Employers are encouraged to request a labour market } \\
\text { assessment (LMA) from the Public Employment Service } \\
\text { (NAV) and enclose it with the application. Otherwise, the } \\
\text { police contact NAV for an LMA. There is a quota for skilled } \\
\text { workers and specialists; beyond this quota, prior LMA is } \\
\text { required. Work permits are not granted if the post can be } \\
\text { filled by domestic labour, and the position must require } \\
\text { specific skills possessed by the candidate. }\end{array}$ & $\begin{array}{l}\text { Regional employment service must authorise employer } \\
\text { following publication with Public Employment Service and } \\
\text { local media. }\end{array}$ \\
\hline Shortage occupation list & $\begin{array}{l}\text { Immediate Skill Shortage Lists (ISSL) } \\
\text { Long Term Skill Shortage List (LTSL) }\end{array}$ & No & No \\
\hline $\begin{array}{l}\text { Foreign students can } \\
\text { change status after the } \\
\text { completion of their } \\
\text { studies }\end{array}$ & $\begin{array}{l}\text { Yes, people who have completed in New Zealand a } 3 \text { year } \\
\text { course or a qualification that would qualify under Skilled } \\
\text { Migration Category; may be granted a work permit for a } \\
\text { maximum of } 6 \text { months to enable them to look for work }\end{array}$ & $\begin{array}{l}\text { Possible, foreign students with a job offer after graduation } \\
\text { may be granted a work permit for up to } 1 \text { year if they did not } \\
\text { benefit from a grant from their origin country or a } \\
\text { cooperation programme. }\end{array}$ & Possible, but no specific programme \\
\hline
\end{tabular}


DELSA/ELSA/WD/SEM(2009)5

\begin{tabular}{|c|c|c|c|}
\hline & PORTUGAL & SLOVAK REPUBLIC & SPAIN \\
\hline $\begin{array}{l}\text { Permanent migration } \\
\text { programmes relevant for } \\
\text { highly skilled workers } \\
\text { PTS: Point system }\end{array}$ & $\begin{array}{l}\text { - Permanent residence permit (after } 5 \text { or } 8 \text { years of } \\
\text { residence depending whether the person is from PALOPS } \\
\text { country -country with Portuguese as official language- or } \\
\text { not) }\end{array}$ & - Permanent residence permit (after 3 years of residence) & $\begin{array}{l}\text { - Permanent residence permit (after } 5 \text { years of legal } \\
\text { residence) }\end{array}$ \\
\hline $\begin{array}{l}\text { Main temporary } \\
\text { migration programmes } \\
\text { relevant for highly } \\
\text { skilled workers } \\
\text { \#Y : maximum duration } \\
\text { R : renewable } \\
\text { LMT : labour market test }\end{array}$ & $\begin{array}{l}\text { - Work permit type II } 1 Y R \text { (to carry out a scientific research } \\
\text { activity or an activity that requires highly qualified technical } \\
\text { skills -including doctors and nurses) } \\
\text { - Work permit type IV } 1 Y R \text { LMT (IEFP list) }\end{array}$ & - Work Permit 1YR LMT & $\begin{array}{l}\text { - Work permit B type 1YR LMT (limited to specific activities } \\
\text { and area; can be renewed for } 2 \text { years) } \\
\text { - Work permit C type } 3 Y \text { LMT (after B type permits; no } \\
\text { restriction) } \\
\text { - Permits D and E for self employed }\end{array}$ \\
\hline Quota & Yes, with some exceptions & No & Yes, only for anonymous hiring (contingente) \\
\hline $\begin{array}{l}\text { Characteristics of the } \\
\text { Labour Market Test }\end{array}$ & $\begin{array}{l}\text { 30-day job listing requirement with the Public Employment } \\
\text { Service. Possibility of an exclusion list where no } \\
\text { authorisation is granted, although this has not been used. }\end{array}$ & The Labour Office has 30 days to approve the request. & $\begin{array}{l}\text { "Negative certification" is required for General Regime } \\
\text { workers. Job must be listed with public employment } \\
\text { service for } 15 \text { days, and employers must interview } \\
\text { candidates sent by the Public Employment Service, } \\
\text { although they are allowed to reject them. However, no } \\
\text { LMT is applied for shortage list occupations. }\end{array}$ \\
\hline Shortage occupation list & No & No & $\begin{array}{l}\text { Regional shortage list (Catalogo de occupations de dificil } \\
\text { cobertura) }\end{array}$ \\
\hline $\begin{array}{l}\text { Foreign students can } \\
\text { change status after the } \\
\text { completion of their } \\
\text { studies }\end{array}$ & Possible, but no specific programme & Possible, but no specific programme & $\begin{array}{l}\text { Yes, foreign students can have a residence and a work } \\
\text { permit after graduation if they have been in Spain for at least } \\
3 \text { years and did not benefit from a grant from their origin } \\
\text { country or a cooperation programme. }\end{array}$ \\
\hline
\end{tabular}


DELSA/ELSA/WD/SEM(2009)5

\begin{tabular}{|c|c|c|c|}
\hline & SWEDEN & SWITZERLAND & TURKEY \\
\hline $\begin{array}{l}\text { Permanent migration } \\
\text { programmes relevant for } \\
\text { highly skilled workers } \\
\text { PTS: Point system }\end{array}$ & - Permanent Residence Permit (PUT) & $\begin{array}{l}\text { - Settlement permit can be delivered after } 5 \text { years of } \\
\text { residence for EFTA, USA and Canadian nationals or } 10 \\
\text { years for other countries. }\end{array}$ & $\begin{array}{l}\text { - Indefinite work and residence permit (after } 8 \text { years of } \\
\text { legal residence and } 6 \text { years of legal employment) }\end{array}$ \\
\hline $\begin{array}{l}\text { Main temporary } \\
\text { migration programmes } \\
\text { relevant for highly } \\
\text { skilled workers } \\
\text { \#Y : maximum duration } \\
\text { R : renewable } \\
\text { LMT : labour market test }\end{array}$ & - Work Permit 5Y LMT & $\begin{array}{l}\text { - Residence permit 1YR LMT (5YR for EEA nationals) } \\
\text { - Short term permit 1YR LMT once } \\
\text { - Trainee exchange schemes with about } 30 \text { countries } 18 \\
\text { months maximum }\end{array}$ & $\begin{array}{l}\text { - Work permit } 1 \text { YR LMT (can be renewed for up to } 3 \text { years } \\
\text { after one year and then for up to six years) The first } 3 \text { years } \\
\text { with no portability and, after three years, with employer } \\
\text { mobility but not sector mobility. }\end{array}$ \\
\hline Quota & No & $\begin{array}{l}\text { Yes, separate quotas for longer and short term. } 7000(<5 \mathrm{Y}) \\
\text { and } 4000(<1 \mathrm{Y})(2008) \text {. EEA exemption. }\end{array}$ & No \\
\hline $\begin{array}{l}\text { Characteristics of the } \\
\text { Labour Market Test }\end{array}$ & $\begin{array}{l}\text { The Public Employment Service authorises a work permit } \\
\text { only if no Swedish, EU, or EEA workers are available or } \\
\text { who can be trained "within a reasonable time" to fill the } \\
\text { vacancy. }\end{array}$ & $\begin{array}{l}\text { Priority is given to resident workers. } 21 \text { day required listing } \\
\text { with Cantonal Public Employment Service, as well as } \\
\text { EURES and other channels. Federal Office for Migration } \\
\text { must also approve the request. }\end{array}$ & $\begin{array}{l}\text { The public employment service has } 4 \text { weeks to find a } \\
\text { suitable candidate in Turkey before approving the work } \\
\text { permit application. }\end{array}$ \\
\hline $\begin{array}{l}\text { Foreign students can } \\
\text { change status after the } \\
\text { completion of their } \\
\text { studies }\end{array}$ & $\begin{array}{l}\text { No, as a general rule, a foreign student from outside the } \\
\text { EU/EEA/Switzerland must leave after completing his/her } \\
\text { studies. }\end{array}$ & $\begin{array}{l}\text { Possible, but no specific programme, although there is a } \\
\text { quota exemption. }\end{array}$ & Possible, but there is no specific programme \\
\hline
\end{tabular}




\begin{tabular}{|c|c|c|}
\hline & UNITED KINGDOM & UNITED STATES \\
\hline $\begin{array}{l}\text { Permanent migration } \\
\text { programmes relevant for } \\
\text { highly skilled workers } \\
\text { PTS: Point system }\end{array}$ & $\begin{array}{l}\text { - Permanent residence -indefinite leave to remain (after } 5 \text { years of legal residence with a work } \\
\text { permit) - PTS }\end{array}$ & $\begin{array}{l}\text { - EB1 for those of "extraordinary ability" - no employer required } \\
\text { - Employment based immigrant visa EB1, EB2 or EB3 -Green card (H1B visa } \\
\text { holders can ask for a green card after } 6 \text { years) }\end{array}$ \\
\hline $\begin{array}{l}\text { Main temporary migration } \\
\text { programmes relevant for } \\
\text { highly skilled workers } \\
\text { \#Y : maximum duration } \\
\text { R : renewable } \\
\text { LMT : labour market test }\end{array}$ & $\begin{array}{l}\text { - Tier } 1 \text { (General) High Skilled Worker 3YR (no job offer needed, points test covering age, } \\
\text { qualification and field, prior wage, UK experience, sufficient funds and language requirement) } \\
\text { - Tier } 2 \text { Skilled Worker } 3 \text { YR Requires job offer, LMT (no LMT if occupation included the shortage } \\
\text { occupation list), and points test covering qualifications, expected wages, language, sufficient } \\
\text { funds. }\end{array}$ & $\begin{array}{l}\text { - H1B visa } 2 Y R \text { maximum } 6 Y \text { (specialty professional workers - bachelor degree or } \\
\text { more : includes doctors and registered nurses). LMT in some cases. H-1B1 for } \\
\text { nationals of Chile and Singapore (special quota) } \\
\text { - TN visa } 1 Y R \text { (NAFTA), NAFTA occupation list includes most health professionals } \\
\text { but physicians only for research and teaching activities } \\
\text { - J1 Visa } 3 Y R \text { maximum } 6 Y \text { (exchange visitor skill) generally must return for } 2 \text { years } \\
\text { to its former country of permanent residence (except if eligible to J1 waiver) } \\
\text { - L1 (intracompany transfer) } 5-7 Y \text { maximum. }\end{array}$ \\
\hline Quota & No & $\begin{array}{l}\text { Yes for H1B }(65000) \text {. Permanent category quotas are EB1 (40 000), EB2 (40 000) } \\
\text { and EB3 (40 000), although "recapture" occurs. No quota for TN, L1 or J1 visa. }\end{array}$ \\
\hline $\begin{array}{l}\text { Characteristics of the } \\
\text { Labour Market Test }\end{array}$ & $\begin{array}{l}\text { The "Resident Labour Market Test" for Tier } 2 \text { requires employers to advertise for an EEA worker, } \\
\text { submitting proof of advertisement within the past } 6 \text { months, information on applicants and } \\
\text { selection process, and justification for not hiring applicants. The Shortage Occupation List } \\
\text { provides an exemption from this test for specific occupations. }\end{array}$ & $\begin{array}{l}\text { For EB2 and EB3 - "permanent labour certification". A shortage list ("Schedule A") } \\
\text { provides an exemption from certification. } \\
\text { For H1B - Internal workplace listing only: } 10 \text { day posting at the workplace, or } \\
\text { electronic distribution to employees, as well as to collective bargaining } \\
\text { representative if relevant. Labour Condition Application is only for verification of } \\
\text { prevailing wage. For "H1B-dependent employers" there is a LMT consisting in } \\
\text { attestation of "non-displacement" of a U.S. worker within } 3 \text { months before and after } \\
\text { request; "good faith" attempts to recruit U.S. workers and an offer of the job to a U.S. } \\
\text { applicant who was equally or better qualified than an H-1B worker. }\end{array}$ \\
\hline Shortage occupation list & Skill shortage occupation list & $\begin{array}{l}\text { Yes "Schedule A" for permanent residence (EB2 and EB3). H-1B is available only for } \\
\text { specified specialty professions. }\end{array}$ \\
\hline $\begin{array}{l}\text { Foreign students can } \\
\text { change status after the } \\
\text { completion of their } \\
\text { studies }\end{array}$ & $\begin{array}{l}\text { Non-EEA student who has obtained a degree level qualification may apply to switch into the } \\
\text { relevant Tier without leaving the UK. The International Graduates Scheme allows graduates to } \\
\text { stay up to } 12 \text { months for work, after which they must switch into a relevant Tier. }\end{array}$ & $\begin{array}{l}\text { Yes, F1 visas allow graduates to stay for up to } 12 \text { months to pursue professional } \\
\text { training ( } 6 \text { months for M1 visa holders) } \\
\text { Within the H1B programme there is special quota (20000) reserved for foreign } \\
\text { students with a Master or PhD from US academic institutions }\end{array}$ \\
\hline
\end{tabular}




\section{BIBLIOGRAPHY}

Canadian Federation of Independent Business. (2006). Immigration and Small Business: Ideas to better respond to Canada's skills and labour shortage. Willowdale, Ontario: Canadian Federation of Independent Business.

CIC (2006), Facts and Figures 2006, Immigration Overview: http://www.cic.gc.ca/EnGLIsh/resources/statistics/facts2006/index.asp

Chiswick, B. R., \& Miller, P. W. (2007). Matching Language Proficiency to Occupation: The Effect on Immigrants' Earnings. IZA Discussion Papers 2587.

Frick, J. (2004). Gutachten zur "Integration von Migranten in Deutschland" auf Basis nationaler und international vergleichbarer Mikrodaten. Berlin: Sachverständigenrat für Zuwanderung Integration.

Grieco, E. (2004). The Foreign Born in the US Labor Force: Numbers and Trends. Washington DC: Migration Policy Institute Fact Sheet No. 4, January 2004.

Longhi, S., Nijkamp, P., \& Poot, J. (2008). Meta-Analysis of Empirical Evidence on the Labour Market Impacts of Immigration. IZA Discussion Papers 3418 .

OECD (2002), "Measures of Skill from Labour Force Surveys”, DSTI/EAS/IND/SWP(2002)13, Paris.

OECD (2006), "Managing Migration - Are Quotas and Numerical Limits the Solutions?", International Migration Outlook 2006, pp. 111-137, Paris.

OECD. (2007a). "Matching Educational Background and Employment: A Challenge for Immigrants in Host Countries", International Migration Outlook 2007, pp. 131-159, Paris.

OECD. (2007b). Jobs for Immigrants - Volume 1: Labour market integration in Australia, Denmark, Germany and Sweden. Paris: OECD.

Picot, Garnett \& Sweetman, A. (2005. "The Deteriorating Economic Welfare of Immigrants and Possible Causes: Update 2005," Analytical Studies Branch Research Paper Series\} 2005262e, Statistics Canada, Analytical Studies Branch.

Rosholm, M., Roed, M., \& Schøne, P. (2006). Are New Work Practices and New Technologies Biased Against Immigrant Workers? IZA Discussion Paper No. 2135. 


\section{OECD SOCIAL, EMPLOYMENT AND MIGRATION WORKING PAPERS}

Most recent releases are:

No. 78 ACTIVATION POLICIES IN NORWAY

Nicola Duell, Shruti Singh and Peter Tergeist (2009)

No. 77 PENSION, PURCHASING-POWER RISK, INFLATION AND INDEXATION Edward Whitehouse (2009)

No. 76 AN EVALUATION OF THE TAX-TRANSFER TREATMENT OF MARRIED COUPLES IN EUROPEAN COUNTRIES

Herwig Immervoll, Henrik Jacobsen Kleven, Claus Thustrup Kreiner and Nicolaj Verdelin (2009)

No. 75 ACTIVATION POLICIES IN IRELAND

David Grubb, Shruti Singh and Peter Tergeist (2009)

No. 74 MAIN FEATURES OF THE PUBLIC EMPLOYMENT SERVICE IN THE CZECH REPUBLIC

Daniela Kaluzna (2008)

No. 73 LONG TIME-SERIES FOR PUBLIC EXPENDITURE ON LABOUR MARKET PROGRAMMES David Grubb and Agnès Puymoyen (2008)

No. 72 MAIN FEATURES OF THE PUBLIC EMPLOYMENT SERVICE IN THE SLOVAK REPUBLIC Daniela Kaluzna (2008)

No. 71 SOCIO-ECONOMIC DIFFERENCES IN MORTALITY

Edward Whitehouse and Asghar Zaidi (2008)

No. 70 INVESTMENT RISK AND PENSIONS: MEASURING UNCERTAINTY IN RETURNS Anna d'Addio, Jose Seisdedod and Edward Whitehouse (forthcoming)

No. 69 FILLING THE PENSION GAP: COVERAGE AND VALUE OF VOLUNTARY RETIREMENT SAVINGS Antolin, P. and Edward Whitehouse (2009) (forthcoming)

No. 68 THE IMPACT OF FOREIGN DIRECT INVESTMENT ON WAGES AND WORKING CONDITIONS Elena Arnal and Alex Hijzen (2008)

No. 67 THE DYNAMICS OF SOCIAL ASSISTANCE RECEIPT: MEASUREMENT AND MODELLING ISSUES, WITH AN APPLICATION TO BRITAIN Lorenzo Cappellari and Stephen P. Jenkins

No. 66 REFORMING RETIREMENT-INCOME SYSTEMS: LESSONS FROM THE RECENT EXPERIENCES OF OECD COUNTRIES

John P. Martin and Edward Whitehouse (2008)

No. 65 THE JOINT DISTRIBUTION OF HOUSEHOLD INCOME AND WEALTH: EVIDENCE FROM THE LUXEMBOURG WEALTH STUDY

Markus Jantti, Eva Sierminska and Tim Smeeding (2008)

No. 64 A REVIEW OF STUDIES ON THE DISTRIBUTIONAL IMPACT OF CONSUMPTION TAXES IN OECD COUNTRIES

Neil Warren (2008)

No. 63 GLOBALISATION AND LABOUR MARKETS: POLICY ISSUES ARISING FROM THE EMERGENCE OF CHINA AND INDIA

David T. Coe (2007)

Other series of working papers available from the OECD include: OECD HEALTH WORKING PAPERS 
DELSA/ELSA/WD/SEM(2009)5

\section{RECENT RELATED OECD PUBLICATIONS:}

PENSIONS AT A GLANCE - SPECIAL EDITION: ASIA/PACIFIC (2009)

GROWING UNEQUAL? Income Distribution and Poverty in OECD Countries (2008)

SICKNESS, DISABILITY AND WORK: BREAKING THE BARRIERS (VOL. 3) - DENMARK, FINLAND, IRELAND AND THE NETHERLANDS (2008)

JOBS FOR YOUTH: JAPAN (2008)

JOBS FOR YOUTH: CANADA (2008)

JOBS FOR YOUTH: NETHERLANDS (2008)

JOBS FOR YOUTH: NEW ZEALAND (2008)

JOBS FOR YOUTH: NORWAY (2008)

JOBS FOR YOUTH: UNITED KINGDOM (2008)

A PROFILE OF IMMIGRANT POPULATIONS IN THE $21^{\text {ST }}$ CENTURY (2008)

OECD EMPLOYMENT OUTLOOK (2008)

OECD LABOUR FORCE STATISTICS: 1987-2007 (2008)

INTERNATIONAL MIGRATION OUTLOOK - 2008 Edition

IMMIGRATION HEALTH WORKERS IN OECD COUNTRIES IN THE BROADER CONTEXT OF HIGHLY SKILLED MIGRATION (2008)

OECD REVIEWS OF LABOUR MARKET AND SOCIAL POLICIES IN SERBIA (2008)

JOBS FOR IMMIGRANTS (VOL. 2): Labour Market Integration in Belgium, France, The Netherlands and Portugal (2008)

MODERNISING SOCIAL POLICY FOR THE NEW LIFE COURSE (2007)

BABIES AND BOSSES - Reconciling Work and Family Life: A Synthesis of Findings for OECD Countries (2007)

BENEFITS AND WAGES - OECD Indicators (2007)

FACING THE FUTURE: KOREA'S FAMILY, PENSION AND HEALTH POLICY CHALLENGES (2007)

PENSIONS AT A GLANCE: Public policies across OECD countries (2007)

JOBS FOR YOUTH: KOREA (2007)

JOBS FOR YOUTH: BELGIUM (2007)

JOBS FOR YOUTH: SPAIN (2007)

JOBS FOR YOUTH: SLOVAK REPUBLIC (2007)

SICKNESS, DISABILITY AND WORK: BREAKING THE BARRIERS (VOL. 2) - AUSTRALIA, LUXEMBOURG, SPAIN AND THE UNITED KINGDOM (2007)

WOMEN AND MEN IN OECD COUNTRIES (2006)

For a full list, consult the OECD On-Line Bookstore at www.oecd.org 